\title{
A new genus of Neotropical rheophilic catfishes, with four new species (Teleostei: Siluriformes: Pseudopimelodidae)
}

\author{
Oscar Akio Shibatta ${ }^{1}$ and Richard P. Vari ${ }^{2 \dagger}$
}

Rhyacoglanis, a new genus of the South American freshwater catfish family Pseudopimelodidae is described from cis-Andean portions of the continent. Rhyacoglanis is distinguished from other genera of the family by three synapomorphies: presence of a light blotch on the cheek; a connection between the middle of the dark caudal-fin stripe and the dark caudal-peduncle pigmentation; and 30-35 total vertebrae. Species of Rhyacoglanis are rheophilic and strongly associated with rapids and other swift-flowing waters. A phylogenetic analysis based on 41 morphological characters yields a hypothesis of monophyly of the Pseudopimelodidae and Rhyacoglanis. Pimelodus pulcher Boulenger, 1887, from the western Amazon basin is designated as type-species of the new genus and redescribed. Four new species are described: Rhyacoglanis annulatus, from the río Orinoco basin, with a nearly ringed dark band on the caudal peduncle, and a larger distance between anus and anal-fin origin; $R$. epiblepsis, from the rio Madeira basin, with numerous dark spots scattered on the body, and rounded caudal-fin lobes; $R$. paranensis, from the upper rio Paraná basin, with three distinct dark bands on the body, and 31-33 total vertebrae; and $R$. seminiger, from the rio Juruena basin, with subdorsal and subadipose dark bands fused anteroposteriorly, and a separate dark band on the caudal peduncle.

Keywords: Biodiversity, Identification key, Phylogeny, Systematics, Taxonomy.

Rhyacoglanis, um novo gênero de bagre da América do Sul da família Pseudopimelodidae é descrito da porção cisandina do continente. Rhyacoglanis é distinto de Pseudopimelodus e outros gêneros da família por três sinapomorfias: uma mancha clara na região lateral da cabeça, a faixa escura da nadadeira caudal confluente ao meio da mancha escura do pedúnculo caudal, e 30-35 vértebras totais. As espécies de Rhyacoglanis são reofílicas com uma forte preferência por corredeiras e outras águas rápidas. Uma análise filogenética com base em 41 caracteres morfológicos produziu uma hipótese de monofilia da família e de Rhyacoglanis. Pimelodus pulcher Boulenger, 1887 é designada a espécie-tipo do gênero novo e redescrita. Quatro espécies novas são descritas: Rhyacoglanis annulatus, da bacia do río Orinoco, com a banda escura do pedúnculo caudal aproximadamente circular, e uma maior distância entre o ânus e a origem da nadadeira anal; $R$. epiblepsis, da bacia do rio Madeira, com o corpo pintalgado e lobos da nadadeira caudal arredondados; $R$. paranensis, da bacia do alto rio Paraná, com três bandas escuras distintas no corpo, e 31-33 vértebras totais; e $R$. seminiger, da bacia do rio Juruena, com uma banda escura larga no tronco composta pelas bandas subdorsal e subadiposa fundidas anteroposteriormente, e uma banda escura separada no pedúnculo caudal.

Palavras-chave: Biodiversidade, Chave de identificação, Filogenia, Sistemática, Taxonomia.

\section{Introduction}

Pseudopimelodidae Fernández-Yépez \& Antón, 1966 is a small family of Neotropical catfishes currently encompassing six genera (Batrochoglanis Gill, 1858; Cephalosilurus Haseman, 1911; Cruciglanis Ortega-Lara \& Lehmann, 2006; Lophiosilurus Steindachner, 1889; Microglanis Eigenmann, 1912; and Pseudopimelodus Bleeker, 1858). In total, these genera include 45 valid species in drainages east of the Andes from the río
Orinoco across the Amazon to the rio Paraná plus the rio São Francisco and coastal rivers of the Guianas. In trans-Andean regions, pseudopimelodids inhabit the Lago Maracaibo basin and several rivers of northwestern Colombia (Eschmeyer, Fong, 2017).

Pseudopimelodids are readily recognized by the combination of small skin-covered eyes, short maxillary and mental barbels, a wide mouth, relatively small heads, stout, serrate dorsal- and pectoral-fin spines and, in particular, various patterns of dark body blotches

${ }^{1}$ Museu de Zoologia, Departamento de Biologia Animal e Vegetal, Centro de Ciências Biológicas, Universidade Estadual de Londrina, 86057-970 Londrina, PR, Brazil.shibatta@uel.br (corresponding author)

${ }^{2}$ Department of Vertebrate Zoology, MRC-159, National Museum of Natural History, P.O. Box 37012, Smithsonian Institution, Washington, D.C. 20013-7012. "deceased before the manuscript was accepted. 
(Shibatta, 1998). Lundberg et al. (1991a) corroborated pseudopimelodid monophyly with five synapomorphies: 1) absence of a spike-like wing of the lateral ethmoid membrane bone projecting beyond the palatine condyle; 2) foreshortened metapterygoid at least twice as broad than long with minimally its dorsal fourth or more deflected medially and usually subtended by a ridge or crest; 3) broad entopterygoid with a sharp anterolateral process and wide comma-shaped ectopterygoid, both bones moveably attached to the neurocranium between the lateral ethmoid-orbitosphenoid suture and the palatine; 4) broad third to seventh (last) proximal dorsal-fin radials in contact for their entire lengths (in genera of moderate to large body sizes) or narrowly separated (in the small sized Microglanis); and 5) absence of the dorsal hypohyal.

Aspects of generic and species-level relationships in the Pseudopimelodidae were explored by various researchers with contradictory conclusions (Mees, 1974; Lundberg et al., 1991a; Shibatta, 1998; Ortega-Lara, Lehmann, 2006; Sullivan et al., 2006; Birindelli, Shibatta, 2011; Sullivan et al., 2013). Mees (1974) assigned Lophiosilurus, Microglanis and Pseudopimelodus to the Pimelodidae. Conversely, Lundberg et al. (1991a) recognized those genera plus Cephalosilurus and Zungaro (Humboldt, 1821) as the Pseudopimelodidae and distant from the Pimelodidae. Lundberg et al. (1991a) proposed four synapomorphies to the clade composed by Zungaro and these other genera. Confusion in specieslevel pseudopimelodid taxonomy at that time led to Lundberg et al. (1991a) misidentification of samples of Pseudopimelodus as Zungaro and of Batrochoglanis as Pseudopimelodus. These issues were resolved, in part, by Silfvergrip (1992) who recognized Zungaro zungaro as the senior synonym of Paulicea luetkeni (Steindachner, 1876) and consequently, a pimelodid.

Numerous authors have discussed the validity of Pimelodus (Pseudopimelodus) pulcher, which Boulenger (1887) described originally from Ecuador. Eigenmann (1890) recognized it as Pseudopimelodus pulcher. Miranda-Ribeiro (1914) described a species from the rio Paraguay basin of southeastern Brazil with a coloration similar to that of $P$. pulcher as Pseudopimelodus variolosus. Mees (1974) considered P. pulcher and $P$. variolosus to be junior synonyms of $P$. zungaro zungaro; a hypothesis rejected by later authors (e.g., Shibatta, 2003a), who recognized $P$. pulcher as valid with $P$. variolosus as a junior synonym.

Analysis of Pseudopimelodus samples from various cis-Andean locations demonstrated that $P$. pulcher is a species complex, most members of which are undescribed. These form a clade broadly ranging across the Amazon basin and portions of the rio Paraná and the río Orinoco drainages. We explore the variation in what was considered P. pulcher, redescribe that species, diagnose a new genus, describe four new species of this new genus, and advance a hypothesis of its monophyly and internal relationships.

\section{Material and Methods}

Morphometrics. Twenty-nine point-to-point measurements were taken to $0.1 \mathrm{~mm}$ with dial calipers on the left when possible (Fig. 1). These are: Anus to anal-fin distance; Adipose-fin base length; Anal-fin base length; Anterior to posterior nostril distance; Body depth; Caudal peduncle depth; Caudal peduncle length; Dorsal-fin base length; Distance between the dorsal and pelvic fins; Distance between pelvic fins; Distance from pelvic fin to anus; Distance between posterior nostrils; Dorsal-fin spine length; Head depth; Head length (HL); Interorbital distance; Length of postcleithral process; Maxillary barbel length; Mouth width; Orbital diameter; Pelvic- to anal-fin distance; Predorsal distance; Pectoral girdle width; Pelvicfin length; Posterior nostril to orbit distance; Prepelvic length; Pectoral-fin spine length; Snout length; Standard length (SL).

Morphometric analysis. Measurements are presented as percentages of SL, except for the subunits of the head, which are presented as percentages of HL. Percents of HL are presented as integer values, because of the higher measurement error.

Principal Component Analysis (PCA) was performed with $\log$ transformed morphometric variables using PAST (Hammer et al., 2001). The first component, which always encompasses the greatest variation is interpreted as representative of size when all original variables are significantly positively correlated with the axis, and the other components, with both positive and negative variables, are decreasing representatives of shape (Jolicoeur, Mosimann, 1960; Neff, Marcus, 1980). The characters contributing most to each axis were identified by examining the eigenvalue loadings.

Counts. Counts were made on the left side of the body when possible. Counts of dorsal-, pectoral-, pelvic-, analand principal and procurrent caudal-fin rays, gill rakers, ribs, branchiostegal rays and vertebrae were taken from $\mathrm{X}$-radiographs of alcohol-preserved specimens and from cleared and stained (c\&s) specimens. Gill-raker counts of the first gill arch are given for epibranchial and ceratobranchial bones. Total vertebrae include the free vertebrae plus the five united vertebrae of the Weberian apparatus. The compound caudal centrum (PU1 + U1) is counted as a single element. Frequencies of counts are presented in parentheses, with the holotype value indicated by an asterisk.

Terminology. Osteological nomenclature follows Lundberg, McDade (1986) as updated by Arratia (2003a; 2003b). Two or, more frequently, three dark, vertical bands are present on the body: the subdorsal band under the dorsal fin, the subadipose band under the adipose fin and the caudalpeduncle band on the caudal-peduncle. Pectoral-fin spine nomenclature was based on Vanscoy et al. (2015). 
SL
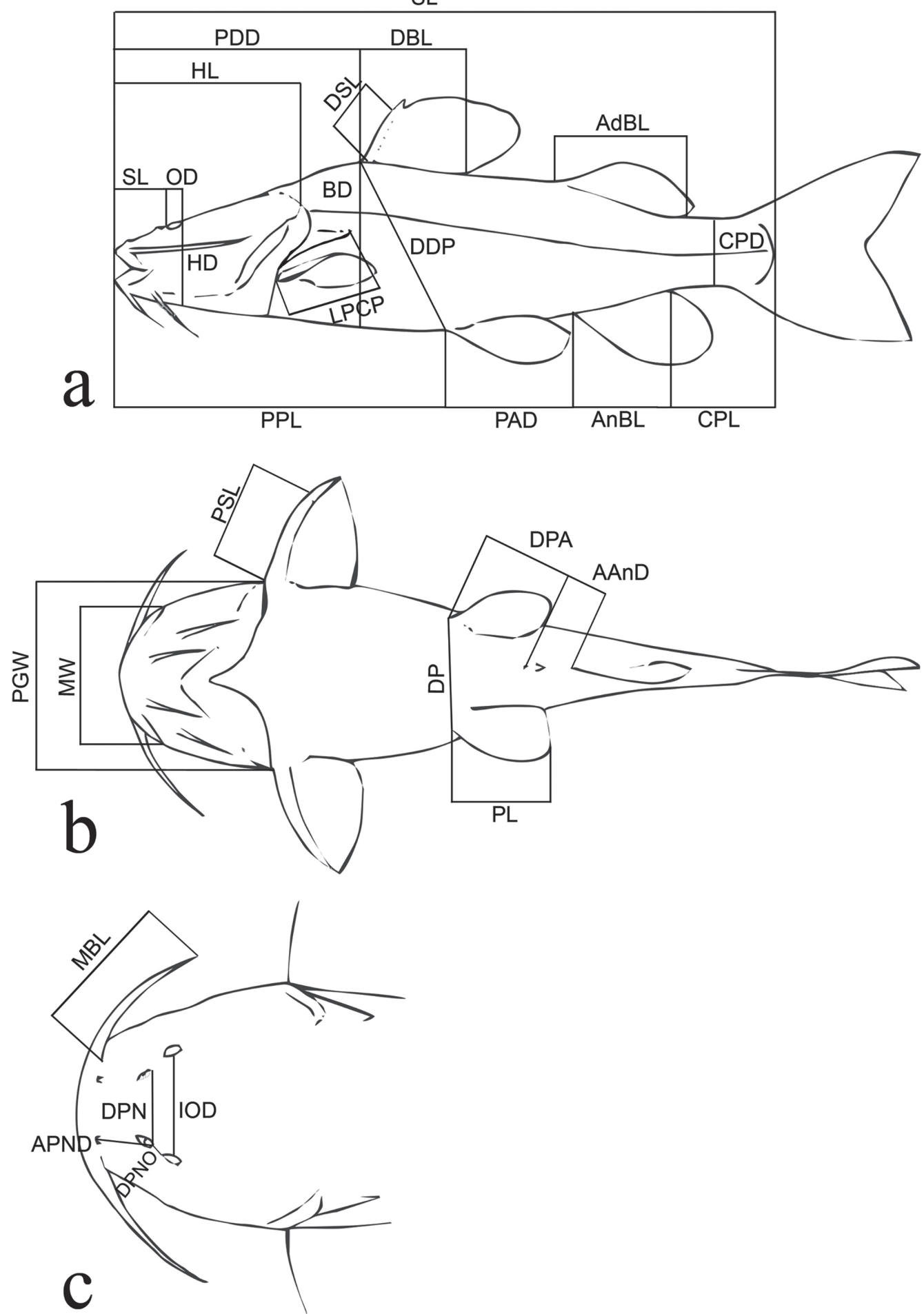

Fig. 1. Landmarks and morphometrics shown on a schematic Rhyacoglanis; a. lateral; b. ventral; and c. dorsal views. Abbreviations: AdBL (Adipose-fin base length); AnBL (Anal-fin base length); APND (Anterior to posterior nostril distance); AAnD (Anus to anal fin distance); BD (Body depth); CPD (Caudal peduncle depth); CPL (Caudal peduncle length); DP (Distance between pelvic fins); DPN (Distance between posterior nostrils); DDP (Distance between the dorsal and pelvic fins); DPA (Distance from pelvic fin to anus); DBL (Dorsal-fin base length); DSL (Dorsal-fin spine length); HD (Head depth); HL (Head length); IOD (Interorbital distance); LPCP (Length of postcleithral process); MBL (Maxillary barbel length); MW (Mouth width); OD (Orbital diameter); PGW (Pectoral girdle width); PSL (Pectoral-fin spine length); PL (Pelvic fin length); PAD (Pelvic to anal fin distance); DPNO (Posterior nostril to orbit distance); PDD (Predorsal distance); PPL (Prepelvic length); SnL (Snout length); SL (Standard length). 
Phylogenetic analysis. In addition to the five species treated herein, one representative species of each genus of the Pseudopimelodidae was included in a parsimony analysis of morphological chraracters. Analysis also included one member each of Pimelodidae (Steindachneridion scriptum) and Heptapteridae (Rhamdia quelen), families hypothesized to be closely related to the Pseudopimelodidae (Sullivan et al., 2013). The analysis was performed using TNT (Goloboff et al., 2008) with implicit weight and traditional search (TBR option), and using Ictalurus punctatus as the outgroup and for tree rooting. Multistate characters were treated as unordered because of lack of prior knowledge about character development and polarity. RI and CI were calculated using the macro script "statsall.run" V. 1.3 developed by Peterson L. Lopes (Universidade de São Paulo), available at Google groups "TNT-Tree Analysis using New Technology $>$ Per character CI and RI". The list of synapomorphies includes only the non-ambiguous synapomoprphies.

Conservation status. The conservation statuses of the new species were assesed according to criteria proposed by International Union for Conservation of Nature and Natural Resources for Red List Categories (IUCN, 2016).

Examined material. Specimens are deposited at American Museum of Natural History, New York (AMNH), Academy of Natural Sciences of Drexel University, Philadelphia (ANSP), Natural History Museum, London (BMNH), California Academy of Sciences, San Francisco (CAS), Field Museum of Natural History, Chicago (FMNH), Laboratório de Biologia e Genética de Peixes, Botucatu (LBP), Laboratório de Ictiologia, Ribeirão Preto (LIRP), Instituto Nacional de Pesquisas da Amazônia, Manaus (INPA), Museo de Biologia de la Universidad Central de Venezuela, Caracas (MBUCV), Museu de Ciências e Tecnologia, Pontifícia Universidade Católica do Rio Grande do Sul, Porto Alegre (MCP), Museo de Historia Natural de la Escuela Politecnia Nacional, Quito (MEPN), Muséum National d'Histoire Naturelle, Paris (MNHN), Museu Nacional, Rio de Janeiro (MNRJ), Museu de Zoologia da Universidade Estadual de Londrina, Londrina (MZUEL), Museu de Zoologia da Universidae de São Paulo, São Paulo (MZUSP), Núcleo de Pesquisas em Limnologia, Ictiologia e Aquicultura, Maringá (NUP), Swedish Museum of Natural History, Stockholm (NRM), Royal Ontario Museum, Toronto (ROM), Universidade Federal do Rio Grande do Sul, Porto Alegre (UFRGS), Universidade Federal de São Carlos, São Carlos (UFSCar), and National Museum of Natural History, Washington DC (USNM).

\section{Results}

\section{Rhyacoglanis, new genus}

urn:1sid:zoobank.org:act:02E3F5D3-5986-4DA9-AC6C4B9A5BDCDCE3
Type-species. Pimelodus (Pseudopimelodus) pulcher Boulenger, 1887.

Diagnosis. Rhyacoglanis is distinguished in the Pseudopimelodidae by three characters, the first two of which autapomorphic: 1) the dorsal and lateral surfaces of the head are grey with a light blotch on the cheek (vs. completely grey in Cruciglanis and Pseudopimelodus, black in Batrochoglanis and Microglanis and ligth in Cephalosilurus and Lophiosilurus); 2) the dark stripe along the midline of the upper and lower caudal-fin lobes is confluent with a dark caudal peduncle blotch (vs. dark stripes on caudal fin not confluent with dark caudal-peduncle pigmentation or absent altogether); 3) 30-35 total vertebrae (vs. 36-44). Rhyacoglanis differs from other pseudopimelodids except Cruciglanis and Pseudopimelodus by the combination of the presence of the vomer, the anterior nostril located slightly posterior of the rictus nearly at the vertical through the posterior of the base of the maxillary barbel, and the thick skin on the pectoral-fin spine. Rhyacoglanis differs from Cruciglanis and Pseudopimelodus in the number of total vertebrae (3135 vs. 41-44 in Cruciglanis; 41-42 in Pseudopimelodus). It differs from Pseudopimelodus in the long posterior cleithral process almost reaching the vertical through the dorsal-fin origin ( $v s$. very short process falling short of that vertical). Rhyacoglanis is distinguished from Cruciglanis by the lack of lateral processes on the second basibranchial (vs. presence of these processes resulting in a cross-shaped ossification) and a pelvic-fin origin at the vertical through the terminus of the dorsal-fin base ( $v s$. slightly posterior of that point). Additional diagnostic characters for Rhyacoglanis in the Pseudopimelodidae are the small maximum body size (less than $100 \mathrm{~mm} \mathrm{SL} v s$. more than $100 \mathrm{~mm}$ SL in Cephalosilurus, Lophiosilurus and Pseudopimelodus); the rounded anterior head outline in dorsal view (vs. an almost trapezoidal head in Lophiosilurus); the terminal mouth opening forward (vs. superior mouth in Lophiosilurus or supraterminal in Cephalosilurus, and Pseudopimelodus); the very wide frontal fontanel ( $v s$. a narrow fontanel in Cruciglanis and Pseudopimelodus); the thin, elongate, arched mesocoracoid in ventral view (vs. triangular in Pseudopimelodus); a posterolaterally projected dentigerous premaxillary plate (vs. projection absent in Microglanis); the laterally expanded anterior transverse process of the fourth vertebrae (vs. unexpanded process in Batrochoglanis, Cephalosilurus, Lophiosilurus and Microglanis); the forked caudal fin with pointed or rounded lobes and a lower lobe usually longer than the upper lobe ( $v s$. an emarginate caudal with the upper lobe longer than the lower lobe in Batrochoglanis and Microglanis, or a round caudal-fin margin in Cephalosilurus and Lophiosilurus); the elongate caudal peduncle (vs. a short peduncle in Batrochoglanis); the adult pigmentation pattern of two or three well-defined dark body bands ( $v s$. bands absent at least at some point in ontogeny in Cephalosilurus and Lophiosilurus); and the 
head pigmentation slightly darker than the ground body coloration ( $v s$. the similar head and body pigmentation in Cephalosilurus and Lophiosilurus).

Etymology. Rhyacoglanis, from the Greek rhyax $=$ torrent + glanis $=$ catfish; indicating a catfish inhabiting running waters in reference to the habitat of the genus. Gender masculine.

\section{Key to species of Rhyacoglanis}

1a. Body with three dark bands - subdorsal, subadipose and caudal peduncle; sometimes inconspicuous or absent..... 2

1b. Body with two dark bands - an anteroposteriorly expansive band formed from a fusion of the subdorsal and subadipose bands, and a separate caudal-peduncle band R. seminiger (rio Juruena basin)

2a. Dorsal regions of subdorsal and subadipose bands separate 3

2b. Dorsal regions of subdorsal and subadipose bands united by dark stripe along dorsal portion of body ...... R. pulcher (western Amazon basin)

3a. Dark caudal-peduncle band uniformly pigmented 4

3b. Dark caudal-peduncle band with unpigmented central section R. annulatus (río Orinoco basin)

4a. Caudal-fin lobes rounded; body covered with multiple small dark spots; dark bands on body inconspicuous to absent R. epiblepsis (rio Madeira basin)

4b. Caudal-fin lobes pointed; body with few small dark spots; dark bands on body conspicuous .

R. paranensis (upper rio Paraná basin)

\section{Rhyacoglanis annulatus, new species}

urn:1sid:zoobank.org:act:0B6E0EF7-5B23-419E-A3D1BF3A827A39CA

\section{Fig. 2; Tab. 1}

Holotype. ANSP 160625, $42.5 \mathrm{~mm}$ SL, Venezuela, Amazonas, río Orinoco, Raudales de Atures, at Culebra, approximately $7 \mathrm{~km} \mathrm{~S}$ of Puerto Ayacucho, $c a .05^{\circ} 35^{\prime} \mathrm{N}$ 67³1'W, 11 Nov 1985, W. G. Saul, R. Royero, O. Brull, L. Aguana \& R. Peck.

Paratype. Venezuela. Amazonas. ANSP192597, 1, 27.0 $\mathrm{mm}$ SL, río Orinoco basin, río Ventuari, exposed cobble beach along base of Cerro Moriche, about $1 \mathrm{~km}$ upstream of Moriche community, $167 \mathrm{~km}$ E-NE of San Fernando de Atabapo, 044' $12.46^{\prime} \mathrm{N} 66^{\circ} 22^{\prime} 21^{\prime \prime} \mathrm{W}, 3$ Apr 2010, M. H. Sabaj Pérez, N. K. Lujan, D. C. Werneke, T. P. Carvalho, S. V. Meza V. \& O. León Mata.
Diagnosis. Rhyacoglanis annulatus is diagnosed from congeners by the caudal-peduncle band with an unpigmented central region (vs. band uniformly dark). Rhyacoglanis annulatus differs from $R$. paranensis in the distance between the anus and anal-fin origin (15.8-16.2 vs. $6.5-12.7 \% \mathrm{SL}$ ), the distance between the pelvic-fin origin and anus $(8.2-9.6 \% v s .9 .9-17.3 \%$ SL) and total vertebrae (31-33 vs. 34-35). Rhyacoglanis annulatus is distinguished from $R$. epiblepsis by distally pointed caudal-fin lobes (vs. rounded), in the distance between the anus and anal-fin origin (15.8-16.2 vs. 11.5-15.0\% SL), the distance between the pelvic-fin origin and anus (8.29.6 vs. $10.0-14.3 \%$ SL), pectoral-fin spine length (8.120.0 vs. $12.6-16.7 \%$ SL), dorsal-fin spine length (16.616.7 vs. 9.8-15.3\% SL), the number of total vertebrae (34$35 v s .31-33$ ), and possession of few dark body spots (vs. numerous less intense spots). Rhyacoglanis annulatus is separable from $R$. seminiger by the separate subdorsal and subadipose bands ( $v s$. bands fused), the distance between the anus and anal-fin origin (15.8-16.2 vs. 6.8-11.6\% SL), the distance between the pelvic-fin origin and anus (8.29.6 vs. 12.4-15.0\% SL) and total vertebrae (34-35 vs. 3133). Rhyacoglanis annulatus is separated from $R$. pulcher in the distance between the anus and anal-fin origin (15.816.2 vs. $13.8-15.2 \%$ SL) and the distance between the pelvic-fin origin and anus (8.2-9.6 vs. 11.1-14.0\% SL).

Description. Body proportions presented in Tab. 1. Body depressed from snout tip to dorsal-fin origin; progressively posteriorly compressed from that point to caudal-fin base. Dorsal profile of posterodorsal portion of head and body nearly straight to dorsal-fin origin; dorsal-fin base inclined slightly posteroventrally and nearly straight; region between posterior terminus of dorsal-fin base and adipose-fin origin nearly straight. Ventral profile of head and body nearly straight from lower jaw margin to posterior of anal-fin base. Caudal peduncle profile slightly concave along dorsal and ventral margins.

Head depressed; slightly longer than wide. Anterior margin convex in dorsal view. Head with well developed unculiferous tubercles primarily dorsally. Mouth terminal and wide; width more than one-half of HL. Upper jaw slightly longer than lower jaw. Lips thick; most developed on lateral surface of lower jaw and proximate to rictus. Premaxillary tooth plate posterolaterally pointed. Anterior nostril located immediately posterior to vertical through rictus. Eye small, superior, covered by skin, slightly posterior of anterior one-third of HL. Opercular membrane well developed; margin reaching pectoral-fin origin. Maxillary barbel base enlarged. Tip of adpressed barbel reaching pectoral-fin origin. Tip of adpressed inner mental barbel extending slightly beyond base of outer mental barbel, but falling short of barbel tip. Tip of adpressed outer mental barbel reaching pectoralfin origin. 


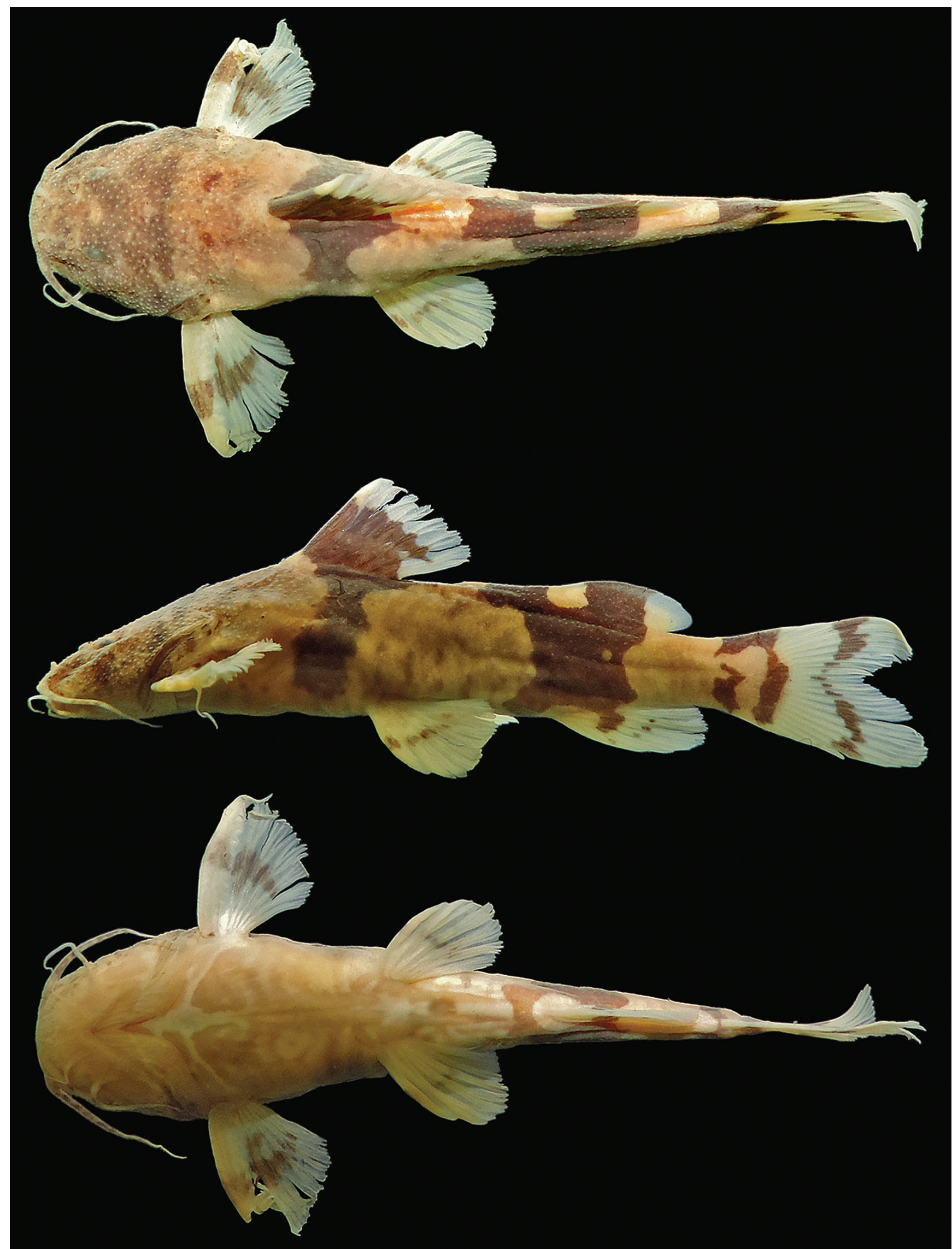

Fig. 2. Rhyacoglanis annulatus, new species, ANSP 160625, holotype, 42.5 mm SL; río Orinoco, Amazonas, Venezuela. 
Tab. 1. Morphometric data for holotype and paratype of Rhyacoglanis anulatus $(\mathrm{N}=2)$.

\begin{tabular}{|c|c|c|}
\hline & Holotype & Paratype \\
\hline Standard length $(\mathrm{mm})$ & 42.5 & 27.0 \\
\hline \multicolumn{3}{|l|}{ Percent of standard length } \\
\hline Head length & 29.2 & 27.4 \\
\hline Pectoral-girdle width & 27.2 & 27.6 \\
\hline Predorsal length & 36.7 & 37.0 \\
\hline Dorsal-fin base length & 17.0 & 14.9 \\
\hline Adipose-fin base length & 28.0 & 22.3 \\
\hline Prepelvic length & 46.9 & 50.1 \\
\hline Distance between pelvic and anal fins & 25.2 & 25.1 \\
\hline Anal-fin base length & 11.1 & 10.1 \\
\hline Caudal-peduncle length & 17.8 & 13.9 \\
\hline Body depth & 19.4 & 17.1 \\
\hline Caudal-peduncle depth & 7.9 & 8.1 \\
\hline Pectoral-fin spine length & 18.1 & 20.0 \\
\hline Dorsal-fin spine length & 16.7 & 16.6 \\
\hline Pelvic-fin length & 18.2 & 19.7 \\
\hline Postcleithral-process length & 12.5 & 12.8 \\
\hline Distance between dorsal and pelvic fins & 25.3 & 22.0 \\
\hline Distance between pelvic fins & 12.4 & 12.5 \\
\hline Distance between pelvic fin and anus & 9.6 & 8.2 \\
\hline Distance between anus and anal fin & 16.2 & 15.8 \\
\hline \multicolumn{3}{|l|}{ Percent of head length } \\
\hline Eye diameter & 11 & 13 \\
\hline Interorbital distance & 34 & 33 \\
\hline Snout length & 39 & 37 \\
\hline Mouth width & 48 & 72 \\
\hline Head depth & 39 & 42 \\
\hline Maxillary-barbel length & 72 & 88 \\
\hline Distance between anterior and posterior nostrils & 22 & 17 \\
\hline Distance between posterior nostril and eye & 10 & 6 \\
\hline Distance between posterior nostrils & 20 & 24 \\
\hline
\end{tabular}

Dorsal fin trapezoidal overall; distal margin rounded; length of longest ray equal to fin-base length. Dorsal-fin origin immediately posterior to anterior one-third of body and anterior to one-half of SL. Tip of adpressed dorsal fin reaching midpoint between dorsal and adipose-fin bases. First dorsal-fin ray (spinelet) small, rigid, and forming dorsal-fin spine-locking mechanism. Second ray a spine with anterior margin smooth and posterior margin with retrorse serrations. Dorsal-fin rays I,6*(2). Adipose fin long; its base longer than that of dorsal fin; posterior margin free and slightly angular. Pectoral fin slightly triangular overall with posterior margin rounded. Tip of adpressed pectoral fin reaching vertical through middle of dorsal-fin base. First pectoral-fin ray strong, rigid and developed as spine with similar size serrae along anterior and posterior margins. Serrations on posterior margin retrorse. Tip of bony pectoralfin spine notched (Fig. 3a). Pectoral-fin rays I,6* rays (2). Pelvic fin almost triangular with posterior margin rounded. Pelvic-fin origin at vertical through base of penultimate dorsal-fin ray. Tip of adpressed pelvic fin falling short of anal fin but extending beyond vertical through adiposefin origin. Pelvic-fin rays i, $5^{*}(2)$. Anal fin margin rounded distally; base shorter than that of adipose-fin. Anal-fin rays iii, $7 *(2)$. Caudal fin forked with pointed lobes; ventral lobe slightly longer than dorsal lobe. Principal caudal-fin rays i, $6,8, i^{*}(2)$. Dorsal procurrent rays $12(1)$ or $14 *(1)$; ventral procurrent rays $9(1)$ or $10 *(1)$.

Posterior cleithral process well developed, pointed, reaching vertical through dorsal-fin origin. Axillary pore present. Lateral line complete. Total vertebrae 34(1) or $35^{*}(1)$. Ribs $9 *(2)$. Gill rakers $1,1,4^{*}(1)$ or $1,1,5(1)$.

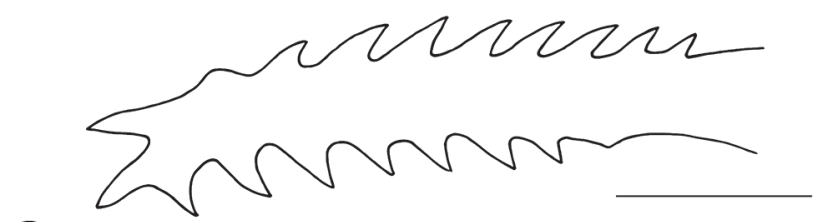

a

b
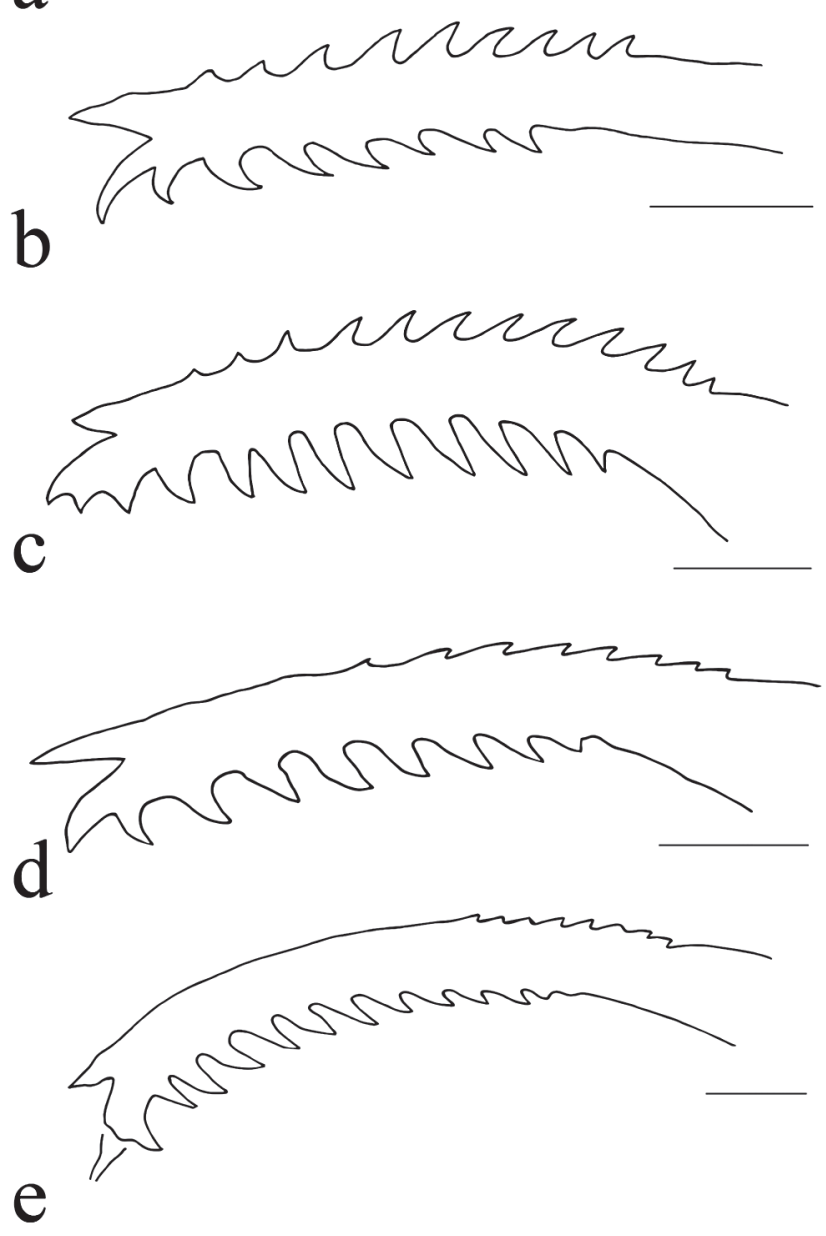

Fig. 3. Ossified portion of left pectoral-fin spine of a. Rhyacoglanis annulatus, holotype, ANSP 160625, $42.5 \mathrm{~mm}$ SL; b. R. epiblepsis, holotype, AMNH 266401, $53.3 \mathrm{~mm} \mathrm{SL;}$ c. $R$. paranensis, holotype, MZUEL 14119, $61.9 \mathrm{~mm}$ SL; d. $R$. pulcher, syntype, BMNH 1880.12.8.105-107, $68.5 \mathrm{~mm}$ SL; e. $R$. seminiger, holotype, LIRP 12466. $74.2 \mathrm{~mm}$ SL. Scale bar $=2.0 \mathrm{~mm}$. 
Color in alcohol. Ground color light brown. Head with dark spots dorsally, on operculum, and ventral to orbit. Region over adductor mandibulae muscle lightly colored. Two small dark spots posterodorsally on head. Subdorsal band narrow, somewhat triangular. Subadipose band nearly rectangular. Region between bands with scattered small, irregularly shaped, dark spots. Caudal-peduncle band irregularly shaped; central region unpigmented. Dorsal fin dark on basal two-thirds and unpigmented posteriorly and distally. Adipose fin with dark pigmentation anteriorly, anterobasally and centrally. Caudal fin hyaline overall with thin arched dark band transversing each lobe; overall pattern resembling sideways $\mathrm{V}$; distal region lightly colored. Anal fin hyaline other than dark blotch near base and series of dark spots aligned across middle of rays. Pectoral and pelvic fins hyaline overall; each crossed by dark stripe.

Geographical distribution. Rhyacoglanis annulatus is known solely from the southern portions of the río Orinoco basin in Venezuela (Fig. 4).

Etymology. The specific name, annulatus, is a Latin adjective meaning ringed, in reference to the caudalpeduncle band with a light inner region.

Conservation status. Only two specimens of $R$. annulatus are known, representing two localities. This rarity in collections suggests that the species may be rare in nature as well. The geographic distribution of $R$. annulatus in the upper río Orinoco basin must be wide, as the localities cover a broad geographic region with up to $40,000 \mathrm{~km}^{2}$. However, in light of extent of occurrence superior to $20,000 \mathrm{~km}^{2}$, and lack of evidence indicating population decline or fluctuations, $R$. annulatus should be assigned a Least Concern (LC) IUCN (2016) status.

Remarks. Rhyacoglanis annulatus is known from two preserved specimens collected in widely separated areas. An internet site (Fluvial, by Oliver Lucanus) (http://www.fluvalaquatics.com/ca/explore/expeditions/ metaexpedition/\#.VP3nn_nF-FU), shows a third specimen identified as Pseudopimelodus cf. raninus which is rather $R$. annulatus as evidenced by the unique caudal-peduncle pigmentation. This specimen from the río Meta represents a distinctly more northwesterly record for the species in the río Orinoco system.

\section{Rhyacoglanis epiblepsis, new species}

urn:1sid:zoobank.org:act:20173235-94FE-4571-BBAAC3D3744692A2

Figs. 5-6; Tab. 2

Pimelodus zungaro zungaro. -Mees, 1974:132, 202, fig. 39, pl. 5 (partim; Bolivia, río Popoi, upper río Beni).

Holotype. AMNH 266401, 53.3 mm SL, Bolivia, Beni, río Itenez, cachuelo approximately $300 \mathrm{~m}$ above mouth of río Machupo, ca. $12^{\circ} 29^{\prime}$ S $64^{\circ} 24^{\prime} \mathrm{W}, 14$ Oct 1964, R. M. Bailey, A. Ximenez, R. Ramos \& D. Anez.

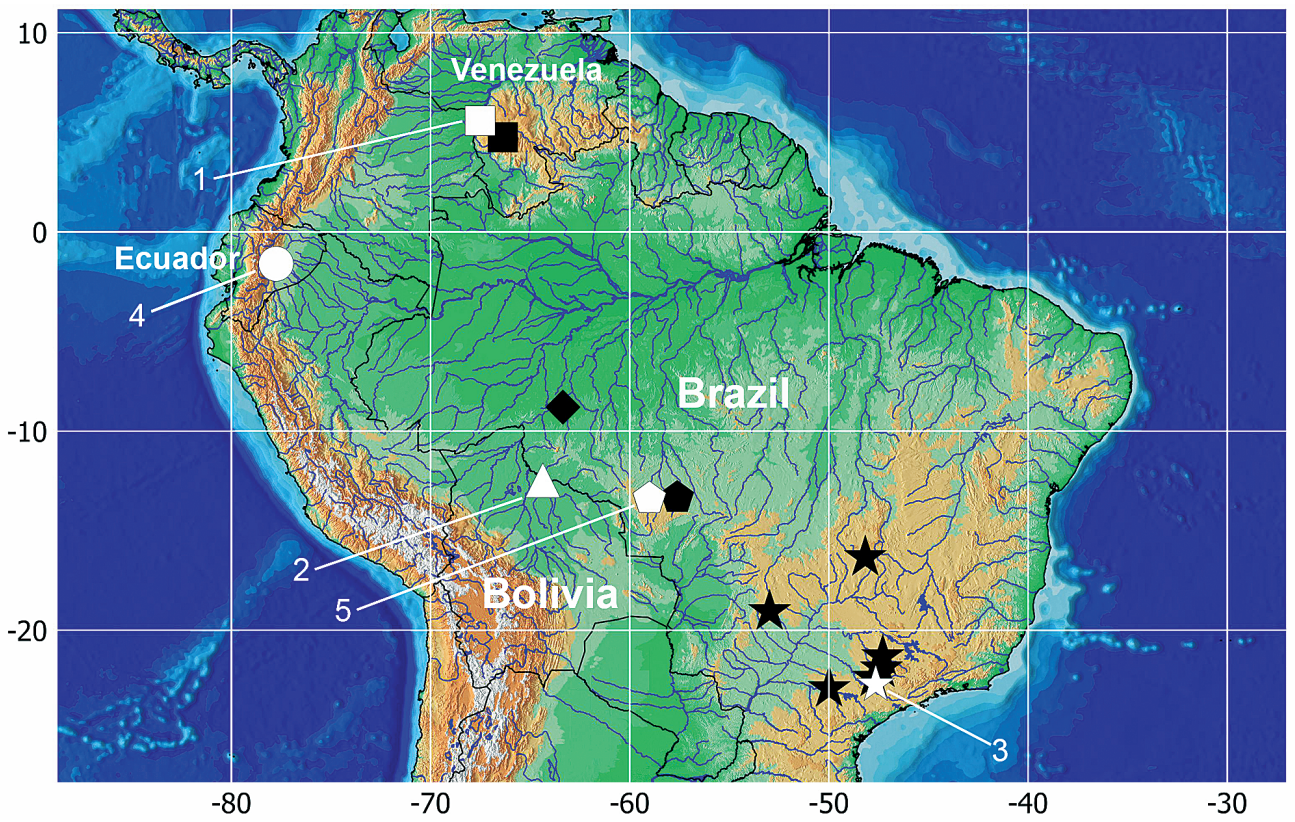

Fig. 4. Map of central portions of South America showing distribution of Rhyacoglanis annulatus (squares; white square $(1)=$ type locality); . epiblepsis (white triangle (2) = type locality); $R$. paranensis (stars; white star $(3)=$ type locality); $R$. pulcher (white circle (4) = type locality); $R$. cf. pulcher (diamond); and $R$. seminiger (pentagon; white pentagon (5) = type locality). Some symbols represent more than one locality and/or lot of specimens. 


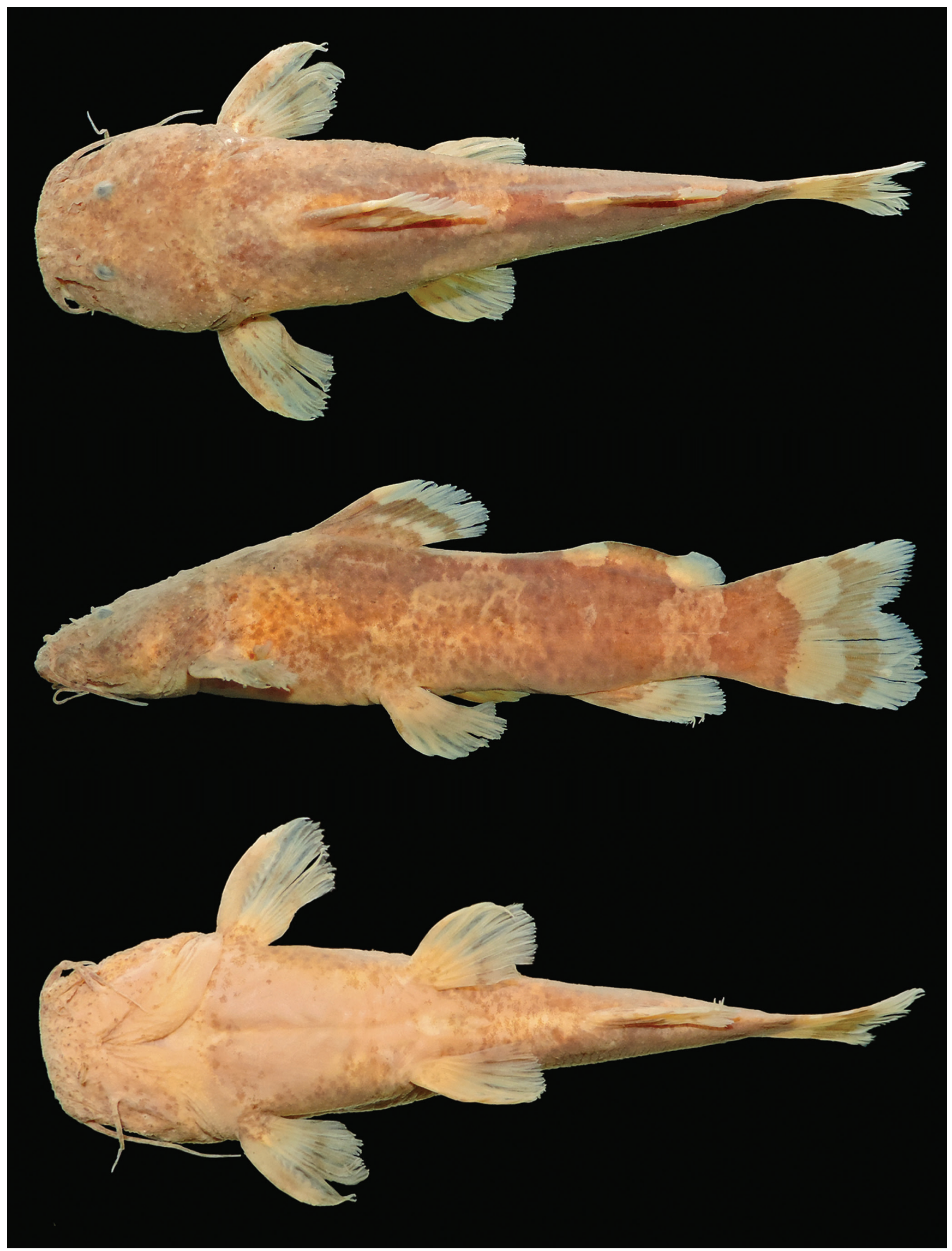

Fig. 5. Rhyacoglanis epiblepsis, new species, AMNH 266401, holotype, 53.3 mm SL; río Itenez, Beni, Bolivia. 


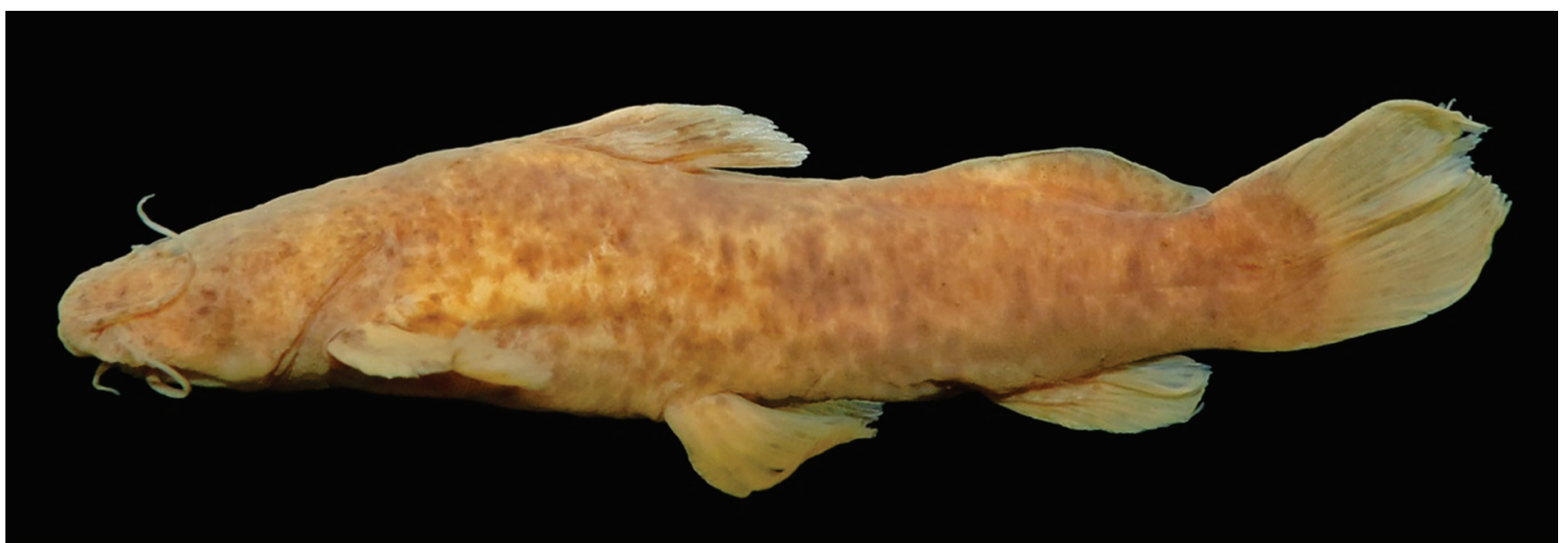

Fig. 6. Rhyacoglanis epiblepsis, paratype, AMNH 40127, $52.0 \mathrm{~mm}$ SL; río Itenez, Beni, Bolivia; showing alternative coloration pattern.

Tab. 2. Morphometric data of Rhyacoglanis epiblepsis $(\mathrm{N}=$ 25). Statistics of minimum (Min), maximum (max), mean, and standard deviation (SD) include holotype.

\begin{tabular}{lccc}
\hline & Holotype & Min-max & Mean $\pm \mathrm{SD}$ \\
\hline Standard length (mm) & 53.3 & $41.0-54.2$ & \\
& Percent of standard length & & \\
Head length & 30.6 & $27.5-30.6$ & $29.2 \pm 0.9$ \\
Pectoral-girdle width & 29.2 & $26.6-29.2$ & $27.9 \pm 0.7$ \\
Predorsal length & 37.2 & $35.3-40.4$ & $37.4 \pm 1.2$ \\
Dorsal-fin base length & 17.6 & $14.6-19.0$ & $17.0 \pm 1.0$ \\
Adipose-fin base length & 21.8 & $17.2-22.9$ & $19.8 \pm 1.4$ \\
Prepelvic length & 48.5 & $48.1-52.8$ & $49.7 \pm 1.3$ \\
Distance between pelvic and anal fins & 25.3 & $24.6-29.2$ & $26.5 \pm 1.4$ \\
Anal-fin base length & 11.9 & $8.3-19.0$ & $11.2 \pm 1.9$ \\
Caudal-peduncle length & 16.2 & $12.0-18.6$ & $14.9 \pm 1.4$ \\
Body depth & 21.4 & $16.8-24.6$ & $20.9 \pm 1.7$ \\
Caudal-peduncle depth & 11.4 & $9.5-11.4$ & $10.5 \pm 0.5$ \\
Pectoral-fin spine length & 16.6 & $12.6-16.7$ & $14.8 \pm 1.1$ \\
Dorsal-fin spine length & 11.7 & $9.8-15.3$ & $12.1 \pm 1.2$ \\
Pelvic-fin length & 18.9 & $15.8-19.8$ & $17.5 \pm 1.0$ \\
Postcleithral-process length & 11.3 & $8.7-12.8$ & $10.7 \pm 1.0$ \\
Distance between dorsal and pelvic fins & 25.8 & $21.6-28.4$ & $25.1 \pm 1.6$ \\
Distance between pelvic fins & 15.1 & $12.8-15.4$ & $14.0 \pm 0.7$ \\
Distance between pelvic fin and anus & 12.3 & $10.0-14.3$ & $12.1 \pm 0.9$ \\
Distance between anus and anal fin & 13.8 & $11.1-15.7$ & $13.8 \pm 1.2$ \\
& \multicolumn{1}{c}{ Percent of head length } & & \\
Eye diameter & 10 & $8-13$ & $10.4 \pm 1.0$ \\
Interorbital distance & 32 & $27-33$ & $29.3 \pm 1.7$ \\
Snout length & 40 & $36-41$ & $37.9 \pm 1.5$ \\
Mouth width & 60 & $51-60$ & $55.7 \pm 3.1$ \\
Head depth & 36 & $32-40$ & $35.4 \pm 2.1$ \\
Maxillary-barbel length & 63 & $49-75$ & $67.3 \pm 6.1$ \\
Distance between anterior and posterior nostrils & 17 & $13-22$ & $17.2 \pm 2.0$ \\
Distance between posterior nostril to eye & 8 & $5-11$ & $8.4 \pm 1.5$ \\
Distance between posterior nostrils & 20 & $13-25$ & $18.7 \pm 2.3$ \\
\hline
\end{tabular}

Paratypes. AMNH 40127, 116 (25 measured), 41.0-54.2 $\mathrm{mm} \mathrm{SL}$, collected with holotype.

Diagnosis. Rhyacoglanis epiblepsis can be distinguished from all congeners by having rounded caudal-fin lobes (vs. pointed lobes). Rhyacoglanis epiblepsis can be differentiated from $R$. annulatus by possessing a uniform caudal-peduncle band ( $v s$. an unpigmented region in the band) and lower total vertebrae (31-33 vs. 34-35). Rhyacoglanis epiblepsis differs from $R$. paranensis by the intensely spotted lateral surface of body ( $v s$. presence of only a few dark spots). Rhyacoglanis epiblepsis is differentiated from $R$. seminiger by the distinct separation of the dark subdorsal and subadipose bands (vs. fusion of those bands) and well developed serrations along the entire anterior pectoral-spine margin ( $v s$. weak serrations limited to the basal portion of the margin). Rhyacoglanis epiblepsis differs from $R$. pulcher in the possession of numerous dark spots on the body ( $v s$. limited spots) and lower number of total vertebrae (31-33 vs. 34-35).

Description. Body proportions are presented in Tab. 2. Body depressed from snout tip to dorsal-fin origin; progressively more compressed from that point to caudal-fin base. Dorsal profile of head and body posterodorsally nearly straight from snout tip to dorsal-fin origin. Dorsal-fin base slightly straight; profile nearly straight from limit of dorsal-fin base to adipose-fin origin. Ventral profile of head and body very slightly convex from margin of lower jaw to end of anal-fin base. Caudal peduncle concave dorsally and ventrally.

Head depressed, slightly longer than wide. Anterior margin very slightly convex in dorsal view. Head with unculiferous tubercles mainly dorsally. Mouth terminal, wide, more than one-half of HL. Upper jaw slightly longer than lower jaw. Lips thick, well developed primarily on lateral surface of jaws. Premaxillary tooth plate with posteriorly pointed projection. Anterior nostril immediately posterior of vertical through rictus. Eye small, superior, 
covered by skin, slightly posterior of anterior one-third of HL. Opercular membrane well developed; margin reaching pectoral-fin base. Maxillary-barbel base enlarged. Tip of adpressed barbel falling short of opercular margin. Adpresssed inner mental barbel extending beyond base of outer mental barbel but falling short of barbel tip. Tip of adpressed outer mental barbel reaching margin of opercular membrane.

Dorsal fin trapezoidal; distal margin rounded; length of longest ray shorter than fin base. Dorsal-fin origin immediately posterior to anterior one-third of body length and anterior to one-half of SL. Tip of adpressed dorsal fin falling short of midpoint between bases of dorsal and adipose fins. First dorsal-fin ray (spinelet) small, rigid, and forming dorsal-fin locking-mechanism. Second ray a spine with anterior margin smooth and posterior margin bearing retrorse serrations. Dorsal-fin rays I, $6^{*}$ rays (15). Adipose fin long; base longer than that of all other fins; posterior extremity free and rounded. Pectoral fin slightly triangular overall with distal margin rounded. Tip of adpressed pectoral fin falling short of pelvic-fin origin. First pectoral-fin ray strong, rigid, and forming spine with retrorse serrations along anterior and posterior margins. Serrations of posterior margin slightly larger, more so distally (Fig. 3b). Pectoralfin rays I, $6^{*}(15)$. Pelvic fin almost triangular with distal margin rounded. Pelvic-fin origin at vertical through base of penultimate dorsal-fin ray. Tip of adpressed pelvic fin falling short of anal-fin origin and of vertical through adipose-fin origin. Pelvic-fin rays i,5*(15). Anal fin rounded distally. Anal-fin rays iii,5(2), iv,5(5), iii,6(7), iv,6*(6), iii,7(2). Caudal fin forked with rounded lobes; lower lobe slightly longer than upper lobe. Principal caudal-fin rays i,6,7,i(2), $\mathrm{i}, 6,8, \mathrm{i} *(18), \mathrm{i}, 7,8, \mathrm{i}(5)$.

Posterior cleithral process well developed and pointed. Axillary pore present. Lateral line with pored portion of variable length; extending posteriorly beyond vertical through posterior limit of adipose-fin base, but falling short of caudal-fin base. Total vertebrae 30(1), 31*(8), 32(14), 33(2). Ribs $9 *(21), 10(4)$. Gill rakers $1,1,2(1) ; 1,1,3(6)$; $1,1,4(2) ; 1,1,5(6)$.

Color in alcohol. Ground color brown. Head with dark spots dorsally, on opercle, and ventral to orbit. Region over adductor mandibulae muscle lightly colored in many specimens. Lateral and dorsolateral surface of body covered by small dark spots. Subdorsal band nearly triangular; subadipose band trapezoidal; caudal-peduncle band with straight anterior and biconcave posterior margins. Dorsal fin with dark stripes basally and across midsection with lightly colored stripes along distal margin and ventral one-third of posterior five rays. Adipose fin with central portion entirely dark brown. Caudal-fin ground coloration light; each lobe with posteriorly arching dark band and lobe margins lightly pigmented. Pectoral, pelvic and anal fins with thin, incomplete, dark stripes. Completely spotted individuals with spots extending onto fins (Fig. 6).
Geographical distribution. Rhyacoglanis epiblepsis is known only from the río Madeira-Mamoré system in Bolivia (Fig. 4).

Etymology. The specific name, epiblepsis, is an adjective from the Greek epi (= up), and blepsis (= act of sight) in reference to the dorsal position of the eyes.

Conservation status. Several specimens of $R$. epiblepsis were collected, potentially indicating that the species is locally common. However, because R. epiblepsis, is known only from the type locality, is it not possible to estimate its actual distribution. Considering the absence of information about its distribution and population dynamics, R. epiblepsis should be assigned a Data Deficient (DD) IUCN (2016) status.

\section{Rhyacoglanis paranensis, new species}

urn:1sid:zoobank.org:act:258CF6F3-FB04-4283-8CC97986EDEFB2B3

Figs. 7-8; Tab. 3

Microglanis sp. -Castro, 1999:150-151 (comments on miniaturization and heterochrony).

Pseudopimelodus aff. pulcher, and New genus pulcher: Langeani et al., 2007:189 and 196 (occurrence in the upper rio Paraná basin).

Pseudopimelodus pulcher. -Birindelli, Shibatta, 2011:891-894 (description of gas bladder).

Holotype. MZUEL 14119, 61.9 mm SL, Brazil, São Paulo,

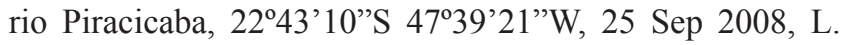
Giuliano-Caetano.

Paratypes. All from Brazil. Minas Gerais. MZUSP 36770, 4, 32.8-38.7 mm SL, Ituiutaba, Salto do Morais, rio Tijuco, 18 56'58"S 49²3'01'W, Oct 1985 - Feb 1986, A. L. Godinho. Mato Grosso do Sul. MZUEL 14121, 1, $89.3 \mathrm{~mm}$ SL, Três Lagoas, Córrego Mimoso, tributary of rio Sucuriú, 1903'8.67"S 52 $58^{\prime} 52^{\prime \prime} W, 7$ Jan 2004, W, L. M. Cordeiro et al. MZUSP 22505, 39, 40.9-16.0 mm SL, Três Lagoas, rio Paraná, in front of Jupiá, $20^{\circ} 15^{\prime} 00^{\prime \prime} \mathrm{S} 51^{\circ} 07^{\prime} 00^{\prime \prime} \mathrm{W}$, Sep 1962, Expedição do Departamento de Zoologia. MZUSP 24448, 11, 49.9-22.2 mm SL, Três Lagoas, Ilha Solteira, 25 28 May 1972, Expedição MZUSP. São Paulo. MCP 14442, 7, 36.1-67.8 mm SL, rio Cubatão, tributary of rio Pardo, near Cajuru, ca. $21^{\circ} 18^{\prime}$ 'S $47^{\circ} 1^{\prime}$ W; 7 Nov 1989, W, R. M. C. Castro. MZUSP 22931, 20, 35.3-23.8 mm SL, Pirassununga, rio Mogi Guaçu, Cachoeira de Emas, ca. $21^{\circ} 55^{\prime} \mathrm{S} 47^{\circ} 23^{\prime} \mathrm{W}$, Feb 1964, Expedição do Departamento de Zoologia. MZUEL 12159, 12, 33.7-27.6 mm SL, Pirassununga, rio

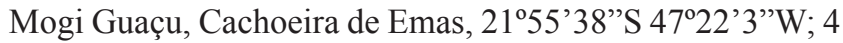
Aug 1994, L. Giuliano Caetano. MZUSP 107932, 14, 62.539.4 mm SL, Ipeúna, rio Passa Cinco, tributary of Rio Tietê, 
$22^{\circ} 25^{\prime} 30^{\prime \prime S} 47^{\circ} 41^{\prime} 49^{\prime \prime} \mathrm{W}, 1$ Jun 2006, O. Moreira Filho et al. MZUEL 2381, 1, 38.3 mm SL, Ourinhos, rio Paranapanema, under railroad bridge, 2300'36"S 4954'18”W, 24 Jun 1992, Duke Energy International. Paraná. MZUEL 6034, 10, 44.638.7 mm SL, Itambaracá, rio Paranapanema, fish ladder at Canoas I Dam, 2256'24'S 50³1'7'W, 17 Mar 2005,
Equipe de Coleta de Peixes da UEL. NUP 3844, 2, 41.8-44.0 $\mathrm{mm}$ SL, Santa Fé, rio Bandeirante do Norte, tributary of Rio Pirapó, 2300'26"S 5147'54'W, 13 Sep 2004, NUPELIA. MZUEL 14120, 89, 38.2-32.2 mm SL, Cornélio Procópio, rio Laranjinha, $23^{\circ} 17^{\prime} 50^{\prime \prime} \mathrm{S} 50^{\circ} 28^{\prime} 43^{\prime \prime} \mathrm{W}, 21$ Jan 2009 , Galindo et al.

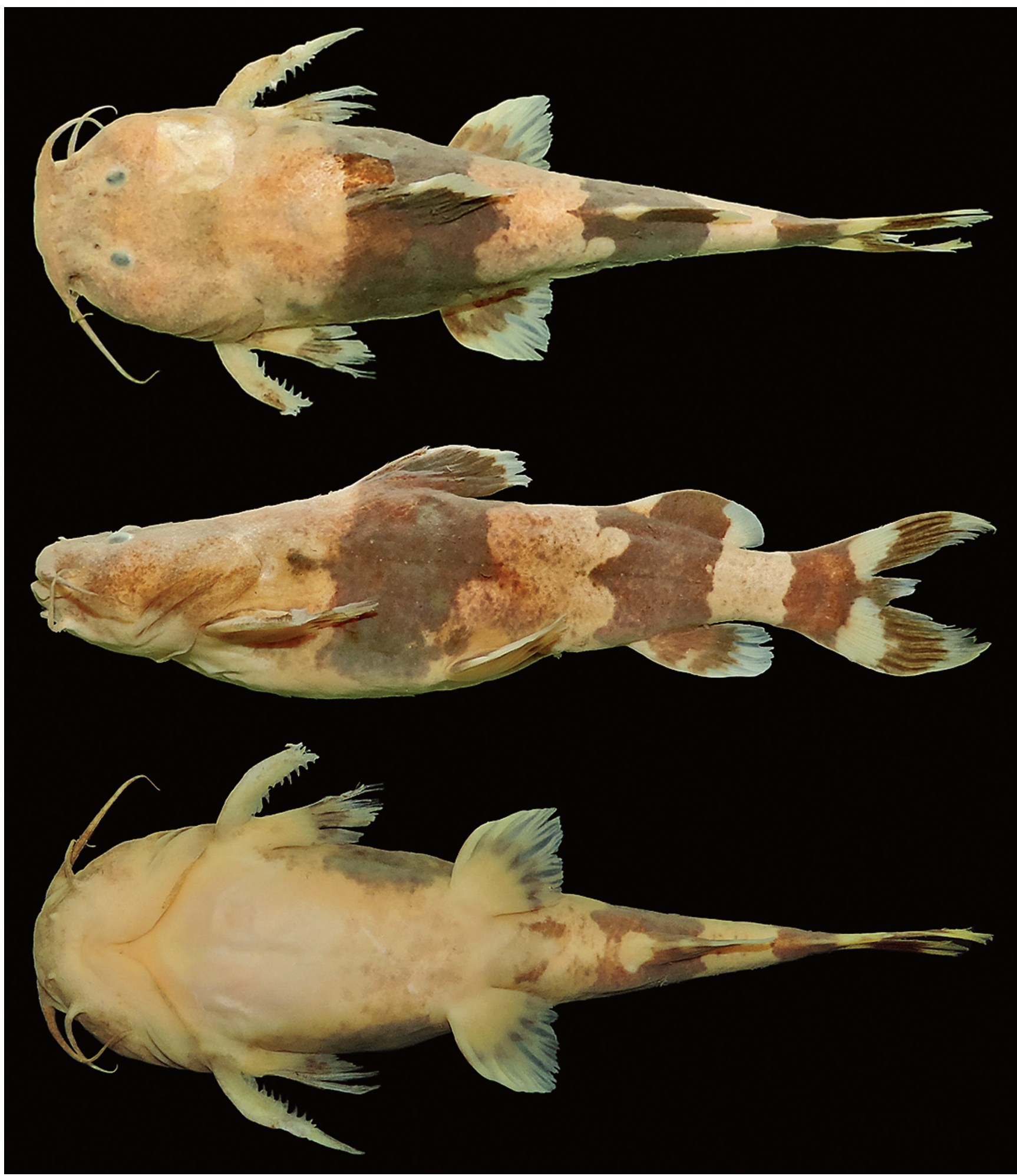

Fig. 7. Rhyacoglanis paranensis, new species, MZUEL 14119, holotype, $61.9 \mathrm{~mm}$ SL, rio Piracicaba, São Paulo, Brazil. 


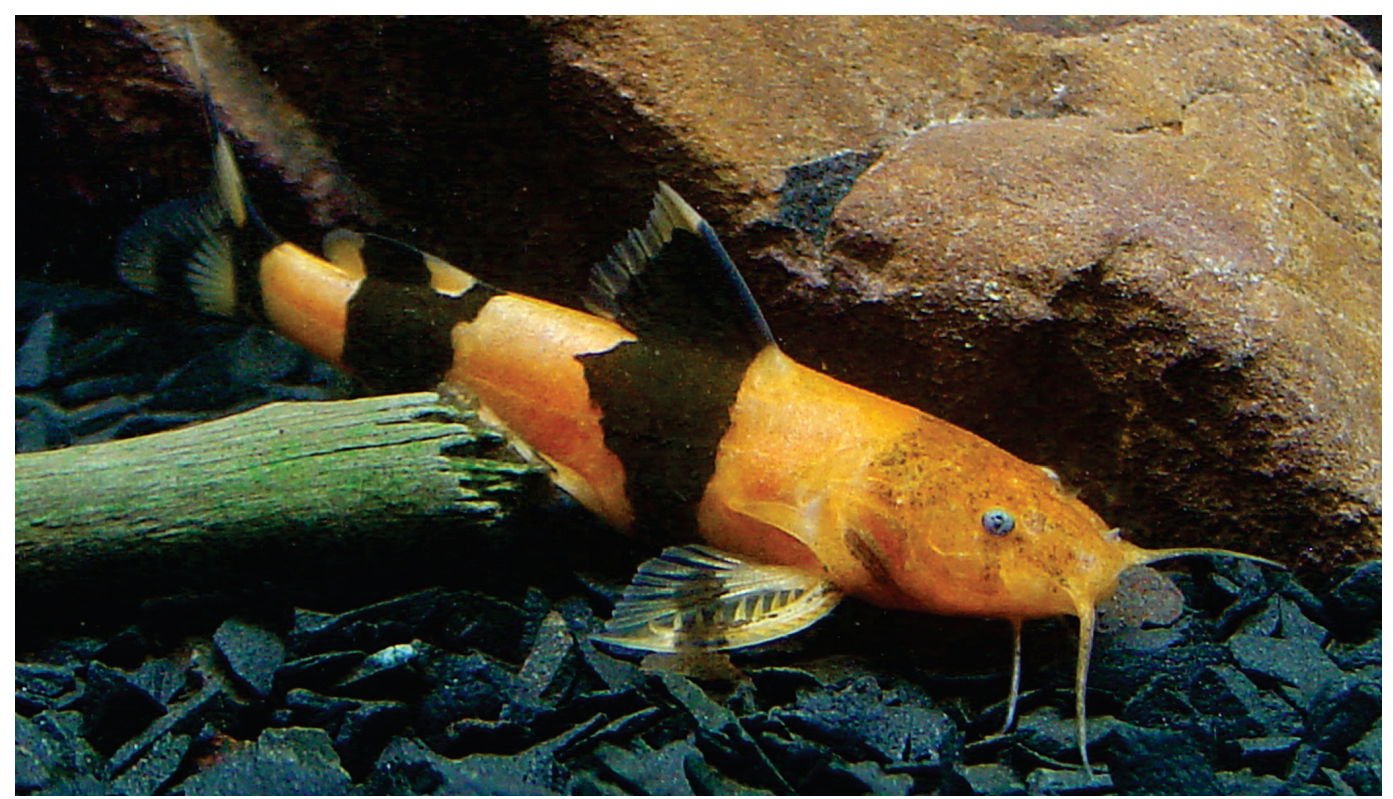

Fig. 8. Live individual of Rhyacoglanis paranensis from Brazil, São Paulo, rio Paranapanema (not retained). Photo by Rony Suzuki.

Tab. 3. Morphometric data of Rhyacoglanis paranensis $(\mathrm{N}=34)$. Statistics of minimum (Min), maximum (max), mean, and standard deviation (SD) include holotype.

\begin{tabular}{|c|c|c|c|}
\hline & Holotype & Min-max & Mean \pm SD \\
\hline Standard length & 61.94 & $32.8-89.2$ & \\
\hline \multicolumn{4}{|c|}{ Percent of standard length } \\
\hline Head length & 29.1 & 25.9-30.8 & $28.3 \pm 1.0$ \\
\hline Pectoral-girdle width & 31.1 & 24.1-32.4 & $26.8 \pm 2.1$ \\
\hline Predorsal length & 35.4 & $34.3-38.7$ & $36.5 \pm 0.9$ \\
\hline Dorsal-fin base length & 18.4 & 13.4-18.6 & $16.9 \pm 1.0$ \\
\hline Adipose-fin base length & 20.5 & $14.6-20.5$ & $17.0 \pm 1.5$ \\
\hline Prepelvic distance & 53.3 & $47.3-55.6$ & $50.1 \pm 1.8$ \\
\hline Distance between pelvic and anal fins & 24.4 & $12.9-27.1$ & $23.6 \pm 3.0$ \\
\hline Anal-fin base length & 9.8 & 8.6-13.6 & $10.7 \pm 1.0$ \\
\hline Caudal-peduncle length & 15.3 & 14.3-18.0 & $16.4 \pm 1.0$ \\
\hline Body depth & 26.3 & $18.2-32.7$ & $21.4 \pm 2.6$ \\
\hline Caudal-peduncle depth & 9.0 & $7.6-9.9$ & $8.8 \pm 0.5$ \\
\hline Pectoral-fin spine length & 17.3 & $14.0-21.7$ & $18.8 \pm 1.8$ \\
\hline Dorsal-fin spine length & 13.5 & $11.3-20.2$ & $17.4 \pm 2.1$ \\
\hline Pelvic-fin length & 19.0 & $16.4-23.7$ & $19.9 \pm 1.6$ \\
\hline Postcleithral-process length & 14.7 & $11.5-15.8$ & $13.9 \pm 1.2$ \\
\hline Distance between dorsal and pelvic fins & 28.8 & $21.7-33.2$ & $24.5 \pm 2.4$ \\
\hline Distance between pelvic fins & 15.6 & $13.2-16.7$ & $14.3 \pm 0.8$ \\
\hline Distance between pelvic fin and anus & 15.5 & $9.9-17.3$ & $13.9 \pm 1.3$ \\
\hline Distance between anus and anal fin & 8.3 & $6.5-12.7$ & $10.0 \pm 1.4$ \\
\hline \multicolumn{4}{|c|}{ Percent of head length } \\
\hline Eye diameter & 10 & $8-13$ & $10.3 \pm 1.1$ \\
\hline Interorbital distance & 33 & $30-41$ & $33.4 \pm 2.3$ \\
\hline Snout length & 36 & $33-44$ & $37.3 \pm 2.0$ \\
\hline Mouth width & 56 & $39-67$ & $51.8 \pm 5.5$ \\
\hline Head depth & 51 & $33-51$ & $41.7 \pm 4.2$ \\
\hline Maxillary-barbel length & 65 & $49-89$ & $74.8 \pm 8.7$ \\
\hline Distance between anterior and posterior nostrils & 14 & $14-26$ & $18.4 \pm 2.8$ \\
\hline Distance between posterior nostril and eye & 7 & $4-9$ & $6.7 \pm 1.3$ \\
\hline Distance between posterior nostrils & 20 & $15-30$ & $21.2 \pm 2.7$ \\
\hline
\end{tabular}

Diagnosis. Rhyacoglanis paranensis differs from $R$. annulatus by possessing a uniformly dark caudal peduncle band (vs. a band with an unpigmented central region), a wide subdorsal band (vs. a narrower band), a lower number of total vertebrae (31-33 vs. 34-35), a greater distance between the pelvic-fin and anus (9.9-17.3 vs. 8.2-9.6\% SL), and a shorter distance between the anus and anal fin (6.5-12.7 vs. 15.8-16.2\% SL). Rhyacoglanis paranensis is differentiated from R. epiblepsis by the pointed caudal-fin lobes (vs. rounded lobes), presence of only a few dark body spots ( $v s$. many body spots of less intense pigmentation). Rhyacoglanis paranensis differs from $R$. seminiger by possessing distinctly separated subdorsal and subadipose bands (vs. fused bands), continuity between dark pigmentation on the caudal-fin lobes (vs. separation of the pigmentation on those lobes) and presence of discrete, dark transverse pectoral and pelvic-fin stripes ( $v s$. fins largely uniformly dark). Rhyacoglanis paranensis differs from $R$. pulcher in the lack of dorsal and ventral confluence between the dark subdorsal and subadipose bands (vs. dorsal and ventral continuity of those bands), in the lack of confluence between subadipose and caudal-peduncle bands (vs. dorsal and ventral continuity of those bands) and possession of lower number of total vertebrae (31-33 vs. 33-35).

Description. Body proportions in Tab. 3. Body depressed from snout tip to dorsal-fin origin; progressively more compressed from that point to caudal-fin base. Dorsal profile of head and anterodorsal portion of body nearly straight from snout tip to dorsal-fin origin but slightly concave along occipital region. Dorsal-fin base nearly straight with slight posteroventral incline. Body profile nearly straight from end of dorsal-fin base to adipose-fin origin. Ventral profile of head and body convex from lower jaw margin to end of anal-fin base, almost straight from anus to anal-fin origin. Caudal peduncle profile concave dorsally and ventrally. 
Head depressed; wider than long. Anterior outline of head convex in dorsal view. Head with undeveloped unculiferous tubercles laterally and dorsally. Mouth terminal, wide; width greater than one-half HL. Upper jaw slightly longer than, or same length as, lower jaw. Lips thick, well developed mainly close to rictus. Premaxillary tooth plate posterolaterally pointed. Anterior nostril located immediately posterior to vertical through rictus. Eye small, superior, covered by skin, slightly posterior to anterior one-third of HL. Opercular membrane well developed; margin reaching pectoral-fin origin. Maxillary-barbel base enlarged. Tip of adpresssed barbel reaching pectoral-fin origin. Adpressed inner mental barbel extending posteriorly slightly beyond outer mental-barbel base but falling short of barbel tip. Tip of adpressed outer mental barbel reaching margin of opercular membrane but falling short of pectoralfin origin.

Dorsal fin trapezoidal with distal margin rounded and longest ray equal to dorsal-fin base. Dorsal-fin origin immediately posterior to anterior one-third of body, but anterior to one-half of SL. Tip of adpressed dorsal fin falling short of midpoint between dorsal-fin insertion and adipose-fin origin. First dorsal-fin ray (spinelet) small, rigid, and forming dorsal-fin spine-locking mechanism. Second dorsal-fin ray spinous; smooth anteriorly and with retrorse serrations posteriorly. Dorsal-fin rays I,6*(29). Adipose fin long; base length similar to that of dorsal fin; posterior extremity free and angular. Pectoral-fin profile triangular overall; posterior margin semi-circular. Tip of adpressed pectoral fin falling short of pelvic-fin origin. First pectoral-fin ray a strong, rigid spine with retrorse serrations along entirety of anterior and posterior margins. Posterior serrations somewhat larger than anterior serrations. Tip of pectoral-fin spine notched (Fig. 3c). Pectoral-fin rays $i, 6 *(27)$. Pelvic fin almost triangular with posterior margin rounded. Pelvic-fin origin at vertical through base of penultimate dorsal-fin ray. Tip of adpressed pelvic-fin reaching adipose-fin origin. Pelvic-fin rays i,5*(31). Analfin margin rounded posteriorly. Anal-fin base shorter than adipose-fin base. Anal-fin rays iii, $5 *(2)$, iii,6(6), iii,7(1), iv,5(2), iv,6(16), or iv,7(2). Caudal fin forked with lobes pointed; ventral lobe slightly longer than dorsal lobe. Principal caudal-fin rays i,6,7,i(1), i,6,7,ii(2), or i,6,8, i*(29). Dorsal procurrent rays 12(2), 13(10), 14(5), 15(8), 16*(2), $17(2)$, or 18(2); ventral procurrent rays $9(3), 10(5), 11(16)$, $12(3)$, or $13 *(3)$.

Posterior cleithral process well developed, pointed, reaching vertical anterior of dorsal-fin origin. Axillary pore present. Lateral line complete. Total vertebrae 31(1), $32 *(15)$, or $33(16)$. Ribs $8 *(26)$, or $9(6)$. Gill rakers $0,1,4(1)$, $1,1,3 *(4), 1,1,4(12), 1,1,5(13), 1,1,6(3), 2,1,3(2), 2,1,4(2)$, $2,1,5(4)$, or $2,1,7(1)$.

Color in alcohol and in life. Ground color light brown in alcohol; light orange in life (Fig. 8). Head with dark spots on dorsal surface, opercle, and region ventral to orbit. Region over adductor mandibulae muscle lightly colored. Iris dark in alcohol; light gray in life. Dark subdorsal band with irregular anterior and posterior margins; extending to ventral region of body but not contacting contralateral counterpart. Subadipose band with irregular anterior and nearly straight posterior margins. Lightly colored region between subdorsal and subadipose bands with scattered dark spots. Anterior margin of caudal-peduncle band nearly straight and posterior margin in shape of shallow, posteriorly open sideways V. Dorsal fin with dark pigmentation covering fin other than for distal one-fifth. Adipose fin with dark blotch centrally. Anal fin with dark basal spot and dark stripe on midsection; two regions conjoined posteriorly. Caudal fin hyaline basally with broad dark band across each lobe and lobe tips largely hyaline. Pectoral and pelvic fins hyaline except for transverse dark stripe on each.

Geographical distribution. Rhyacoglanis paranensis is only known from the upper rio Paraná basin in Brazil (Fig. 4).

Etymology. The specific name, paranensis, is an adjective in reference to the occurrence of the species in the upper rio Paraná basin.

Conservation status. Several specimens of $R$. paranensis were obtained from collections, suggesting that the species is not rare. Furthermore, the geographic distribution of $R$. paranensis in the upper rio Paraná basin must be wide, as the localities cover a broad geographic region of approximately $500,000 \mathrm{~km}^{2}$. The construction of several hydroelectric power plants along the upper rio Paraná will likely fragment the species distribution by destroying the preferred habitat in rapids, and represents a potential threat to $R$. paranensis. However, in light of the extent of occurrence exceeding $20,000 \mathrm{~km}^{2}$, and lack of evidence indicating population decline or fluctuation, we recommend assigning $R$. paranensis an IUCN (2016) conservation status of Least Concern (LC).

\section{Rhyacoglanis pulcher (Boulenger, 1887), new combination}

Figs. 9-10; Tab. 4

Pimelodus (Pseudopimelodus) pulcher Boulenger, 1887:276, pl. xxi, figs. 1, 4 (original description; Ecuador, Canelos).

Pseudopimelodus pulcher. -Eigenmann, Eigenmann, 1888:111. Batrachoglanis pulcher. -Eigenmann, 1910:383 (eastern Ecuador). Microglanis pulcher. -Eigenmann, 1912:155 (observations on color pattern).

Microglanis pulcher. -Gosline, 1941:85 (Ecuador, Canelos).

Pimelodus zungaro zungaro. -Mees, 1974:202, fig. 39, pl. 5 (partim; Ecuador, Canelos; not Bolivia, upper río Beni; Peru, río Marañon; Brazil, Mato Grosso, Sangadina).

Pseudopimelodus pulcher. -Shibatta, 2003a:404 (information on synonyms, maximum length, and distribution). 


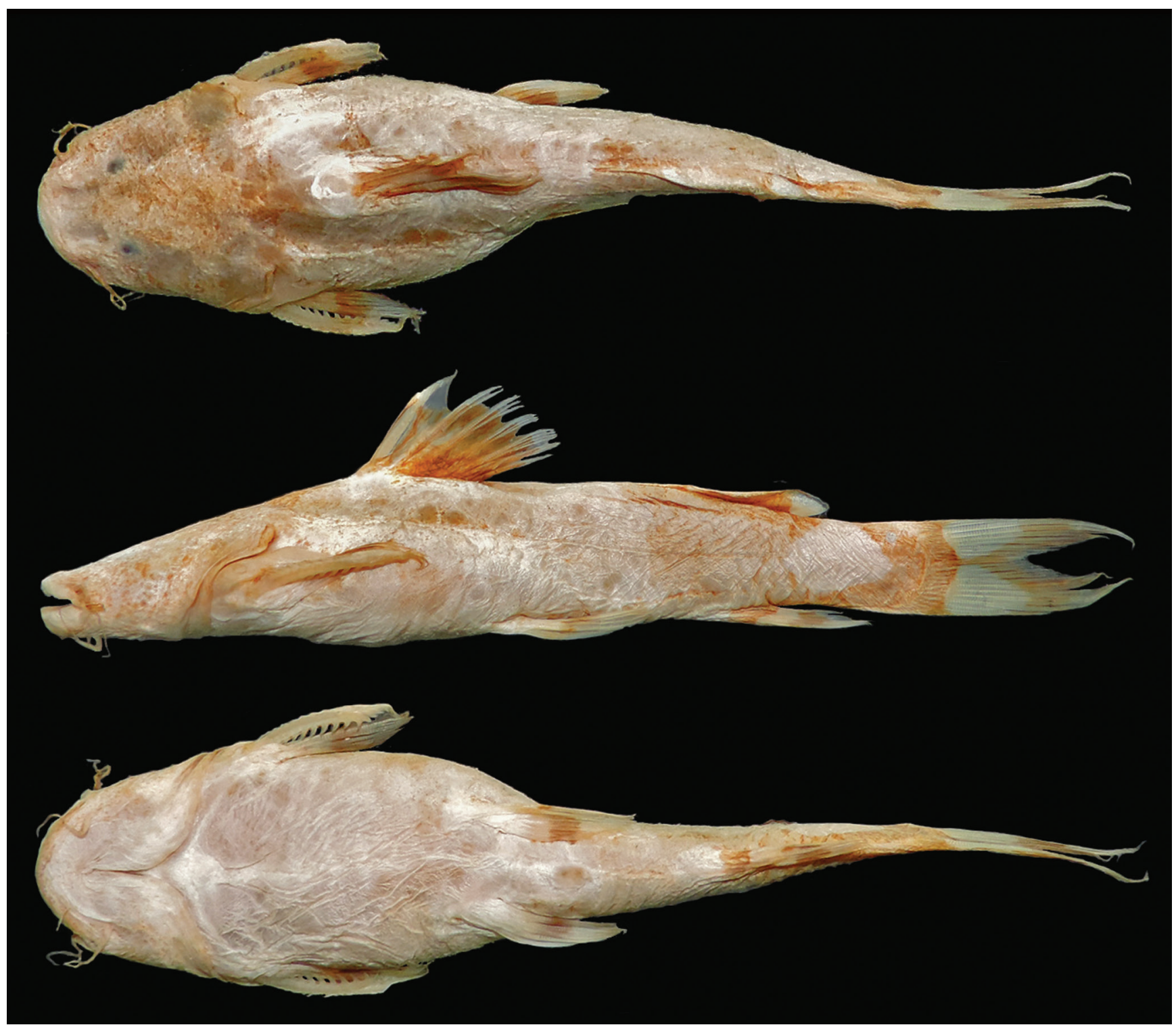

Fig. 9. Rhyacoglanis pulcher, BMNH 1880.12.8.105-107, syntype, 68.5 mm SL; Canelos, Ecuador.

\section{P. Z. S. 1887. Pl. XXI.}



Peter Smit del.et lith.

1. PIMELODUS PULCHER



Fig. 10. Original illustration of syntype of Rhyacoglanis pulcher showing entire specimen in lateral view and anterior portion in dorsal view (modified from Boulenger, 1887). 
Tab. 4. Morphometric data of syntypes of Rhyacoglanis pulcher $(\mathrm{N}=3)$.

\begin{tabular}{|c|c|c|c|}
\hline & Syntype 1 & Syntype 2 & Syntype 3 \\
\hline Standard length $(\mathrm{mm})$ & 68.5 & 67.4 & 58.5 \\
\hline \multicolumn{4}{|c|}{ Percent of standard length } \\
\hline Head length & 28.6 & 28.3 & 29.1 \\
\hline Pectoral-girdle width & 27.8 & 26.5 & 27.6 \\
\hline Predorsal length & 36.1 & 34.8 & 36.1 \\
\hline Dorsal-fin base length & 15.6 & 16.8 & 15.8 \\
\hline Adipose-fin base length & 20.9 & 15.1 & 19.3 \\
\hline Prepelvic length & 51.0 & 51.4 & 52.8 \\
\hline Distance between pelvic and anal fins & 24.5 & 24.4 & 26.7 \\
\hline Anal-fin base length & 11.9 & 9.8 & 10.7 \\
\hline Caudal-peduncle length & 17.8 & 18.0 & 15.6 \\
\hline Body depth & 16.9 & 18.1 & 17.9 \\
\hline Caudal-peduncle depth & 10.0 & 9.8 & 10.1 \\
\hline Pectoral-fin spine length & 16.4 & 15.6 & 18.4 \\
\hline Dorsal-fin spine length & 12.9 & 13.6 & 17.2 \\
\hline Pelvic-fin length & 18.2 & 18.8 & 20.0 \\
\hline Postcleithral-process length & 11.7 & 10.6 & 11.0 \\
\hline Distance between dorsal and pelvic fins & 24.5 & 26.9 & 25.0 \\
\hline Distance between pelvic fins & 13.1 & 14.2 & 13.5 \\
\hline Distance between pelvic fin and anus & 12.9 & 11.1 & 14.0 \\
\hline Distance between anus and anal fin & 15.2 & 13.8 & 14.4 \\
\hline \multicolumn{4}{|c|}{ Percent of head length } \\
\hline Eye diameter & 6 & 8 & 6 \\
\hline Interorbital distance & 30 & 31 & 36 \\
\hline Snout length & 37 & 36 & 39 \\
\hline Mouth width & 54 & 48 & 63 \\
\hline Head depth & 34 & 35 & 33 \\
\hline Maxillary-barbel length & 71 & 71 & 80 \\
\hline Distance between anterior and posterior nostrils & 18 & 19 & 17 \\
\hline Distance between posterior nostril and eye & 6 & 8 & 6 \\
\hline Distance between posterior nostrils & 18 & 24 & 24 \\
\hline
\end{tabular}

Material examined. Ecuador. Canelos. BMNH 1880.12.8.105107, 3, syntypes, 58.5-68.5 mm SL, Upper Amazon River basin, 1880, C. Buckley.

Diagnosis. Rhyacoglanis pulcher is distinguished from $R$. paranensis by the dorsal and ventral confluence of the dark subdorsal and subadipose bands (vs. separation of those bands) and total number of vertebrae (34-35 vs. 31-33). Rhyacoglanis pulcher differs from $R$. annulatus in the uniformly dark caudal-peduncle band ( $v s$. band centrally light), distance from the pelvic-fin origin to the anus (11.1-14.0 vs. 8.2-9.6\% SL) and distance from the anus to the anal-fin origin (13.8-15.2 vs. $15.8-16.2 \% \mathrm{SL})$. Rhyacoglanis pulcher is distinguished from $R$. epiblepsis by the pointed caudal-fin lobes (vs. rounded lobes), the very obvious body bands (vs. obscure or absent bands) and limited number of dark spots on the body ( $v s$. spots numerous and not dark). Rhyacoglanis pulcher is diagnosed from $R$. seminiger by the confluence of the dark subdorsal and subadipose bands limited to dorsal and ventral regions (vs. bands completely fused), stripes on caudal fin continuous with the caudal-peduncle spot (vs. distinctly separated) and total vertebrae (34-35 vs. 32-33).

Description. Body proportions are given in Tab. 4. Body depressed from snout tip to dorsal-fin origin; progressively compressed from that point to caudal-fin base. Dorsal profile of head and body posterodorsally nearly straight from snout tip to dorsal-fin origin; dorsal-fin base slightly straight; profile nearly straight from terminus of dorsal-fin base to adipose-fin origin. Ventral head and body profile slightly convex to almost straight from lower jaw margin to posterior limit of anal-fin base. Caudal peduncle profile slightly concave along dorsal and ventral margins.

Head depressed; slightly longer than wide. Anterior margin convex in dorsal view. Head with weakly developed scattered unculiferous tubercles laterally and dorsally. Mouth terminal and wide; width more than one-half of HL. Upper jaw slightly longer than, or same length as, lower jaw. Lips thick and well developed, more so proximate to rictus. Premaxillary tooth plate posterolaterally pointed. Anterior nostril immediately posterior to vertical through rictus. Eye small, superior, covered by skin, slightly posterior to anterior one-third of HL. Opercular membrane well developed; margin falling short of pectoral-fin origin. Maxillary barbel base enlarged. Tip of adpressed maxillary barbel falling short of opercular margin. Tip of adpressed inner mental barbel surpassing base of outer mental barbel but falling short of tip of that barbel. Tip of adpressed outer mental barbel reaching opercular membrane margin.

Dorsal-fin trapezoidal with distal margin rounded and first branched ray longer than dorsal-fin base. Dorsal-fin origin immediately posterior to anterior one-third of body but anterior to one-half of SL. Tip of adpressed dorsal fin reaching slightly beyond midpoint between dorsal-fin base terminus and adipose-fin origin. First dorsal-fin ray (spinelet) small, rigid and forming dorsal-fin spine-locking mechanism. Second ray in form of spine with anterior margin smooth and posterior margin bearing retrorse serrations. Dorsal-fin rays I,6(3). Adipose fin long; base longer than that of other fins; posterior margin free and rounded. Pectoral-fin margin somewhat triangular overall with posterior margin rounded. Tip of adpressed pectoral fin falling short of pelvic-fin origin. First pectoral-fin ray strong, rigid and in form of spine with serrae along anterior and posterior margins; posterior serrations retrorse and distinctly larger than anterior serrae; pectoral-fin spine notched distally (Fig. 3d). Pectoral-fin rays I,5(1) or I,6(2). Pelvic-fin profile almost triangular; posterior margin rounded. Pelvic-fin origin immediately posterior to vertical through terminus of dorsal-fin base. Tip of adpressed pelvic fin reaching vertical through adiposefin origin. Pelvic-fin rays i,5(3). Anal-fin margin rounded; base shorter than that of adipose fin. Anal-fin rays iii,7(2) or iv,6(1). Caudal fin forked; lobes pointed; ventral lobe slightly longer than, or almost same length as, dorsal lobe. Caudal-fin principal rays i, $6,8, i$. Dorsal procurrent rays $17(2)$ or 18(1); ventral procurrent rays $15(1), 16(1)$, or 17(1). 
Posterior cleithral process well developed, pointed, reaching vertical through anterior of dorsal-fin base. Axillary pore present. Lateral line complete. Total vertebrae 34(2), 35(1). Ribs 9(1), 10(1) or 11(1). Gill rakers $1,1,3(1)$ or $1,1,4(2)$.

Color in alcohol. Pigmentation faded in examined specimens. Ground color light brown. Head with dark spots dorsally and ventral to eye. Body with dark subdorsal, subadipose and caudal-peduncle bands. Subdorsal band somewhat triangular, ventrally narrower and extending to ventral region of body with dorsal and ventral extensions continuous with subadipose band. Subadipose band overall rectangular with dorsal and ventral anterior and posterior extensions continuous with similar extensions of subdorsal and caudal-peduncle bands. Caudalpeduncle band with anterior margins extending along border forming a distinct anteriorly directed sideways V. Dorsal fin covered by dark band other than along distal one-fifth. Adipose fin with large dark central spot. Anal fin with two dark transverse stripes. Caudal fin hyaline other than for arched dark distal band on each lobe; bands of each lobe confluent on middle caudal-fin rays; dark pigmentation continuing anteriorly to caudal peduncle band; overall dark pigmentation in form of posteriorly directed sideways Y. Pectoral fin hyaline other than for transverse dark stripe slightly posterior to middle of fin. Pelvic fin with curved dark transverse stripe near midlength (Figs. 9-10).

Geographical distribution. Rhyacoglanis pulcher occurs in the Ecuadorian Amazon (Fig. 4). Though Mees (1974) indicated that $R$. pulcher also occurs in the río Popoi in the upper río Beni in Bolivia, the río Marañón in Peru, and at Sangadina, Mato Grosso, Brazil, we were unable to examine and confirm the identification of the specimens from the two last localities and the latter in particular represents a questionably unusually great range extension. The río Beni specimens reported on by Mees (1974) are rather R. epiblepsis, described herein.

Conservation status. Few specimens of $R$. pulcher were obtained from collections, suggesting that the species may be naturally rare. However there is a possibility that $R$. pulcher has a wider distribution in the rio Amazonas basin. In the absence of the information about geographic distribution and population dynamics necessary to properly evaluate the extent of occurrence, we recommend assigning an IUCN (2016) status of Data Deficient (DD) to $R$. pulcher.

Remarks. After nearly 150 years of preservation, the syntypes of Pseudopimelodus pulcher are very soft with faded coloration. However, the residual pigmentation in these specimens agrees closely with the illustration presented by Boulenger (1887), suggesting that the drawing can be taken as an accurate depiction of the original pigmentation. Most features were accurately described in the original description. Boulenger commented, however, that the "band of teeth in the upper jaw is of moderate breadth, without prolonged lateral portion"; whereas we find that the tooth band is actually posteriorly pointed.

A sample from the rio Jamari (INPA 9517), a rio Madeira tributary, agrees with the pigmentation pattern and most features of Rhyacoglanis pulcher except for having 7 branched pectoral-fin rays $v s$. the 5-6 rays in the type series. Unfortunately, with only two specimens from the rio Jamari and three from the type locality, it is uncertain whether this difference represents intraspecific variation or is an indication of an undescribed species of Rhyacoglanis in the rio Madeira. We tentatively identify the Madeira population as $R$. cf. pulcher pending study of additional specimens from those regions.

Mees (1974) proposed P. variolosus to be a synonym of $P$. pulcher based on the features reported by MirandaRibeiro (1914). However, the type locality of $P$. variolosus is Coxim, rio Taquary, Mato Grosso State, in a different hydrographic basin than that of $P$. pulcher. Examination of part of the syntype series of $P$. variolosus (lectotype MNRJ 818 and paralectotype MNRJ 16245), and of the description of the species by Miranda-Ribeiro (1914), shows that $P$. variolosus has at least two of the known synapomorphies of Rhyacoglanis, although we were not able to confirm the number of vertebrae, even via radiography. Since our analysis did not allow us to unequivocally confirm the synonymy of $P$. variolosus with $P$. pulcher, we prefer to maintain it as tentatively valid until more specimens from the rio Taquary become available.

\section{Rhyacoglanis seminiger, new species}

urn:1sid:zoobank.org:act:8F27E9DD-CED6-402D-A6F6EAAB04914D0B

Figs. 11-12; Tab. 5

Holotype. LIRP 12466, 74.2 mm SL, Brazil, Mato Grosso, Sapezal, rio Tapajós basin: rio Juruena, Pequena Central Hidrelétrica Cidezal, 13²2’39”S 5900'57’W, 3 Jun 2010, R. J. Hilário.

Paratypes. Brazil. Mato Grosso. LIRP 8042, 9, 48.3$74.8 \mathrm{~mm} \mathrm{SL}$, collected with holotype. MZUEL 14123, 2, 60.4-64.8 mm SL, collected with holotype. MZUSP 82085, 3, 44.4-70.4 mm SL, Campo Novo do Parecis, rio Tapajós basin, rio do Sangue, tributary of the rio Juruena, $13^{\circ} 18^{\prime} 56^{\prime \prime}$ S 57 $35^{\prime} 42^{\prime \prime} W, 18$ Feb 2003, K. de Silimon. MZUSP 118019, 1, 72.4 mm SL, São José do Rio Claro, rio Tapajós basin, rio Claro, tributary of rio Arinos, $13^{\circ} 30^{\prime} 15^{\prime \prime} \mathrm{S}$ 56³7'6.70”'W, 14 Aug 2015, O. T. Oyakawa et al. 

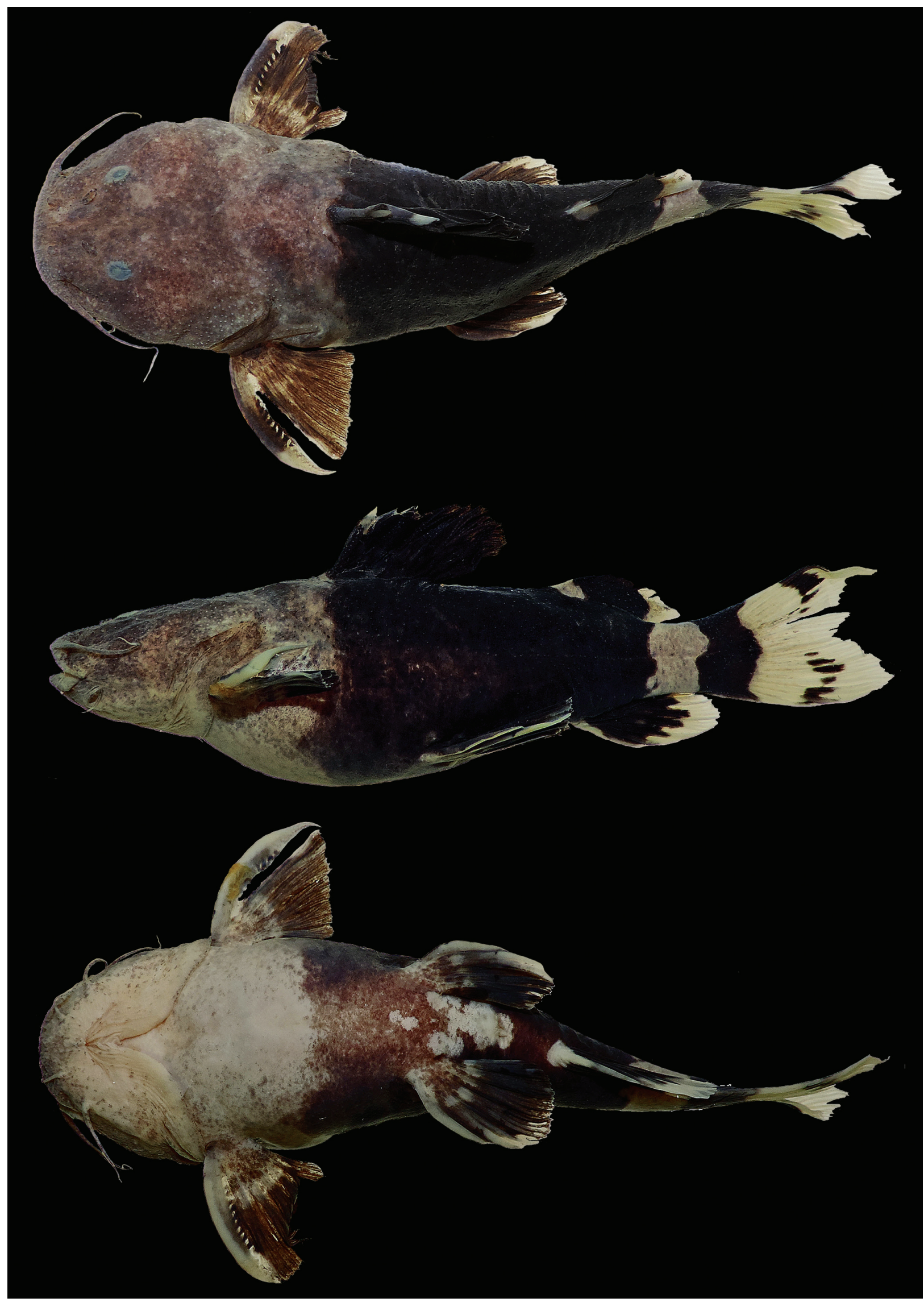

Fig. 11. Rhyacoglanis seminiger, new species, LIRP 12466, holotype, $74.2 \mathrm{~mm}$ SL; rio Juruena, Mato Grosso, Brazil. 



Fig. 12. Color variation in Rhyacoglanis seminiger, MZUSP 82085, paratypes; a. 70.4 mm SL; b. 48.6 mm SL; c. 44.4 mm SL; rio Sangue, tributary of rio Juruena, Mato Grosso, Brazil.

Diagnosis. Rhyacoglanis seminiger differs from all congeners in having the dark subdorsal and subadipose bands seamlessly conjoined ( $v s$. completely separate or joined only dorsally and ventrally by narrow horizontal connecting extensions). Rhyacoglanis seminiger differs from $R$. annulatus in the uniformly dark caudal-peduncle band ( $v s$. band with an unpigmented central section) and total vertebrae (32-33 vs. 34-35). Rhyacoglanis seminiger can be differentiated from $R$. epiblepsis by the pointed caudal-fin lobes ( $v s$. rounded lobes), lack of intensely dark body spotting (vs. such spotting) and weak serrations limited to the base of the anterior margin of the pectoral-fin spine ( $v s$. well developed serrations along the entire anterior margin). Rhyacoglanis seminiger additionally differs from $R$. pulcher in having 32-33 vertebrae (vs. 34-35). 
Tab. 5. Morphometric data of Rhyacoglanis seminiger $(\mathrm{N}=13$ except for dorsal-fin spine length where $\mathrm{N}=12$ ). Statistics of minimum (Min), maximum ( $\max$ ), mean, and standard deviation (SD) include holotype.

\begin{tabular}{lccc}
\hline & Holotype & Min-max & Mean \pm SD \\
\hline Standard length (mm) & 74.2 & $48.3-77.8$ & \\
& Percent of standard length & & \\
Head length & 33.1 & $29.6-34.3$ & $32.2 \pm 1.2$ \\
Pectoral girdle width & 32.3 & $27.4-33.1$ & $30.7 \pm 1.8$ \\
Predorsal length & 38.7 & $36.2-39.5$ & $38.1 \pm 1.0$ \\
Dorsal-fin base length & 18.2 & $16.0-19.8$ & $18.4 \pm 1.1$ \\
Adipose-fin base length & 17.8 & $15.6-20.5$ & $18.1 \pm 1.5$ \\
Prepelvic distance & 56.3 & $50.9-56.3$ & $53.4 \pm 1.9$ \\
distance between pelvic and anal fins & 22.7 & $20.1-26.2$ & $23.1 \pm 1.6$ \\
Anal-fin base length & 10.9 & $8.7-11.7$ & $10.6 \pm 0.7$ \\
Caudal-peduncle length & 14.1 & $13.5-17.2$ & $15.6 \pm 1.0$ \\
Body depth & 29.4 & $17.4-30.0$ & $24.7 \pm 4.0$ \\
Caudal-peduncle depth & 9.5 & $8.9-10.8$ & $10.0 \pm 0.6$ \\
Pectoral-fin spine length & 18.0 & $10.8-20.4$ & $17.6 \pm 2.2$ \\
Dorsal-fin spine length & 14.3 & $13.7-16.8$ & $15.1 \pm 0.8$ \\
Pelvic-fin length & 21.9 & $19.9-22.3$ & $21.1 \pm 0.9$ \\
Postcleithral-process length & 14.5 & $8.6-15.9$ & $13.9 \pm 2.1$ \\
Distance between dorsal and pelvic fins & 31.8 & $23.0-32.0$ & $28.7 \pm 3.1$ \\
Distance between pelvic fins & 14.9 & $13.0-15.8$ & $14.2 \pm 0.8$ \\
Distance between pelvic fin and anus & 14.5 & $12.4-15.5$ & $13.8 \pm 1.0$ \\
Distance between anus and anal fin & 6.8 & $6.8-11.6$ & $8.8 \pm 1.3$ \\
& $\quad$ Percent of head length & & \\
Eye diameter & 10 & $7-11$ & $9.3 \pm 0.9$ \\
Interorbital distance & 33 & $29-34$ & $32.2 \pm 1.7$ \\
Snout length & 37 & $35-40$ & $37.8 \pm 1.5$ \\
Mouth width & 57 & $45-61$ & $53.4 \pm 4.0$ \\
Head depth & 46 & $33-52$ & $43.2 \pm 5.6$ \\
Maxillary-barbel length & 64 & $54-75$ & $66.4 \pm 6.5$ \\
Distance between anterior and posterior nostrils & 13 & $13-17$ & $14.9 \pm 1.3$ \\
Distance between posterior nostril and eye & 7 & $6-8$ & $6.7 \pm 0.8$ \\
Distance between posterior nostrils & 18 & $15-22$ & $20.1 \pm 2.0$ \\
\hline
\end{tabular}

Description. proportional measurements are given in Tab. 5 . Body depressed from snout to dorsal-fin origin, progressively compressed from that point to caudal-fin base. Dorsal profile of head and body slightly convex and posterodorsally nearly straight from snout tip to dorsal-fin origin; dorsal-fin base slightly posteroventrally nearly straight; profile nearly straight from terminus of dorsal-fin base to adipose-fin origin. Ventral profile of head and body convex overall from lower-jaw margin to anus; approximately straight from anus to posterior limit of anal-fin base. Caudal peduncle profile concave dorsally and ventrally.

Head depressed; slightly longer than wide. Anterior margin convex in dorsal view. Head with unculiferous tubercles mainly dorsally. Mouth terminal and wide; width more than one-half of HL. Upper and lower jaws of equal length. Lips thick and well developed, more so on lateral surface of lower jaw and proximate to rictus. Premaxillary tooth plate posterolaterally pointed. Anterior nostril positioned immediately posterior to vertical through rictus. Eye small, superior, covered by skin, positioned slightly posterior of anterior one-third of HL. Opercular membrane well developed; margin reaching pectoral-fin origin. Maxillary-barbel base enlarged. Tip of adpressed barbel reaching pectoral-fin origin but falling short of opercular margin. Tip of adpressed inner mental barbel slightly surpassing outer mental-barbel base but falling short of barbel tip. Tip of adpressed outer mental barbel reaching margin of opercular membrane.

Dorsal fin trapezoidal overall with distal margin rounded; longest ray shorter than length of dorsal-fin base. Dorsal-fin origin immediately posterior of anterior one-third of body but anterior to midpoint of SL. Tip of adpressed dorsal fin falling short of midpoint between dorsal-fin insertion and adipose-fin origin. First dorsal-fin ray (spinelet) small, rigid, and forming dorsal-fin locking-mechanism. Second ray a spine with anterior margin smooth and posterior with retrorse serrations. Dorsal-fin rays I,6* rays (10). Adipose fin long; its base length equal to, or slightly shorter than, length of dorsal-fin base; posterior extremity free and rounded. Pectoral fin triangular overall; posterior margin rounded. Tip of adpressed pectoral fin falling short of pelvic-fin origin. First pectoral-fin ray strong, rigid and forming spine with retrorse very small serrations anteriorly. Posterior serrations extending along entire spine; largest distally. Anterior serrations distinctly smaller that posterior serrations; limited to basal one-half of spine (Fig. 3e). Pectoral-fin rays I,6*(10). Tip of pectoral-fin spine notched. Pelvic fin triangular overall with posterior margin rounded. Pelvic-fin origin at vertical through base of penultimate dorsalfin ray. Tip of adpressed pelvic-fin reaching anal-fin origin and surpassing vertical through adipose-fin origin. Pelvic-fin rays i, $5^{*}(10)$. Anal fin rounded distally; its base shorter than adipose-fin base. Anal-fin rays iv, $5^{*}(6)$, iii,6(1), or iv,6(3). Caudal fin forked with pointed lobes; lower lobe slightly longer than upper lobe. Principal caudal-fin rays i, $6,7, i^{*}(1)$ or $\mathrm{i}, 6,8, \mathrm{i}(9)$. Dorsal procurrent rays $13(1), 14(3), 15^{*}(3)$ or $16(2)$; ventral procurrent rays $11(1), 12 *(6)$, or 13(2).

Posterior cleithral process well developed, pointed and reaching vertical through dorsal-fin origin. Axillary pore present. Lateral line complete. Total vertebrae $32(2)$ or $33^{*}(8)$. Ribs $8 *(9), 9(1)$. Gill rakers 1,1,3*(5), 1,1,4(3), 1,1,5(1), or $1,1,6(1)$.

Color in alcohol. Ground color light brown with dorsal portion of head slightly darker and region over the adductor mandibulae muscle less intensely pigmented. Subtle transverse dark stripe sometimes present from nape to tip of post-cleithral process; when present stripe sometimes darker on nape. Dark subdorsal and subadipose bands conjoined into wide band extending from vertical through dorsal-fin origin nearly to vertical through posterior one third of adipose-fin base. Lightly pigmented horizontal blotch sometime present within band in region between verticals through dorsalfin base terminus and beginning of adipose-fin base. Light colored blotch present at adipose-fin origin. Dark caudalpeduncle band vertically elongate with undulate anterior border and biconcave posterior margin. Some specimens with 
scattered dark dots over lightly colored regions of head and body. Contralateral dark bands conjoined ventrally anterior of pelvic fin, between pelvic and anal fins, and along caudal peduncle. Dorsal fin darkly pigmented other than for narrow, lightly colored band along anterodorsal margin; sometimes with lightly colored region on basal one-third. Adipose fin with dark central region. Caudal-fin lobes with dark stripes or small dots on distal one-half; dark pigmentation restricted to dorsal and ventral portions of upper and lower lobes, respectively. Anal fin with dark basal blotch anteriorly and dark stripe over posterior one-third; patches fused in some individuals. Pectoral fin with broad dark stripe extending over two-thirds of spine and covering progressively more of fin rays medially. Pelvic fin dark basally, followed by unpigmented transverse band and large dark band over most of rest of fin other than for unpigmented marginal stripe.

Geographical distribution. Rhyacoglanis seminiger is only known from the rio Tapajós basin, Mato Grosso, Brazil. The species was collected in rapids of the rio Juruena and the rio Arinos, in the foothills of the Serra do Parecis (Fig. 4).

Ecological notes. The upper rio do Sangue, where some of the paratypes were collected, has very fast-flowing clear waters over a substrate composed nearly exclusively of quartz sand and small rocks, with the river margins covered by riparian forest. The Serra do Parecis foothills hold potential for small hydroelectric power plants that could adversely impact rheophilic species such as $R$. seminiger. Indeed, the rio Juruena specimens originate at one such site (Pequena Central Hidrelétrica Cidezal).

Etymology. The specific name, seminiger, is an adjective from the Latin semi $=$ half, and niger $=$ black, in reference to the dramatically contrasting light $v s$. dark coloration pattern.

Conservation status. Few specimens of $R$. seminiger were obtained from collections, suggesting that the species may be naturally rare. The geographic distribution of $R$. seminiger in the rio Tapajós basin is probably wide, as the known localities cover a broad geographic region of approximately $90,000 \mathrm{~km}^{2}$. The construction of hydroelectric power plants potentially threaten $R$. seminiger, and may result in fragmentation of its distribution by destruction of its preferred habitat in rapids. However, considering the extent of occurrence exceeding $20,000 \mathrm{~km}^{2}$, and lack of evidence indicating current population decline or fluctuations, we recommend assigning an IUCN (2016) status for R. seminiger of Least Concern (LC).

Remarks. Pigmentation features, in particular the fusion of the subdorsal and subadipose bands allows the unequivocal identification of Rhyacoglanis seminiger. Some differences exist, however, in dorsal fin and body band coloration between the rio do Sangue (some individuals with light blotches; Fig. 12) and rio Juruena samples (nearly completely dark). This variation along with the disjunct geographic distribution suggests discrete populations with limited gene flow, or phenotypic plasticity to environmental differences. In the absence of samples from intervening regions, we tentatively consider these to be intraspecifically variable, or conspecifics. If additional samples demonstrate consistent differences, then the rio do Sangue populations may merit recogniton as a new species.

Comparative morphometry. The first three principal components axes account for $92.8 \%$ of the total variance, with the first axis accounting for $84.2 \%$. All variable first axis loadings were positive and presumably of approximately equal magnitude, indicating it reflects the size component. The second and third principal components include positive and negative variable loadings, and help index morphological variation among individuals that helps to differentiate species (Fig. 13). Rhyacoglanis pulcher is easily discriminated along the third component, which indexes its greater anus to analfin distance, dorsal-fin spine length, posterior nostril distance, pectoral-fin spine length, and caudal-peduncle length (all positive loadings; Tab. 6). Rhyacoglanis paranensis and $R$. seminiger differ from $R$. epiblepsis and $R$. annulatus by their greater dorsal-fin spine length, postcleithral process length, body depth and pectoral-fin spine length (all of which load positively on the second axis) and the lesser anus to anal-fin distance, distance between the posterior nostril and the orbit and adipose-fin length (negative loadings in the second axis). Some specimens of $R$. paranensis differ from $R$. seminiger by having longer dorsal and pectoral-fin spines, but these species are overall morphometrically very similar. Rhyacoglanis annulatus and $R$. epiblepsis (Fig. 13) also share similar measurements.

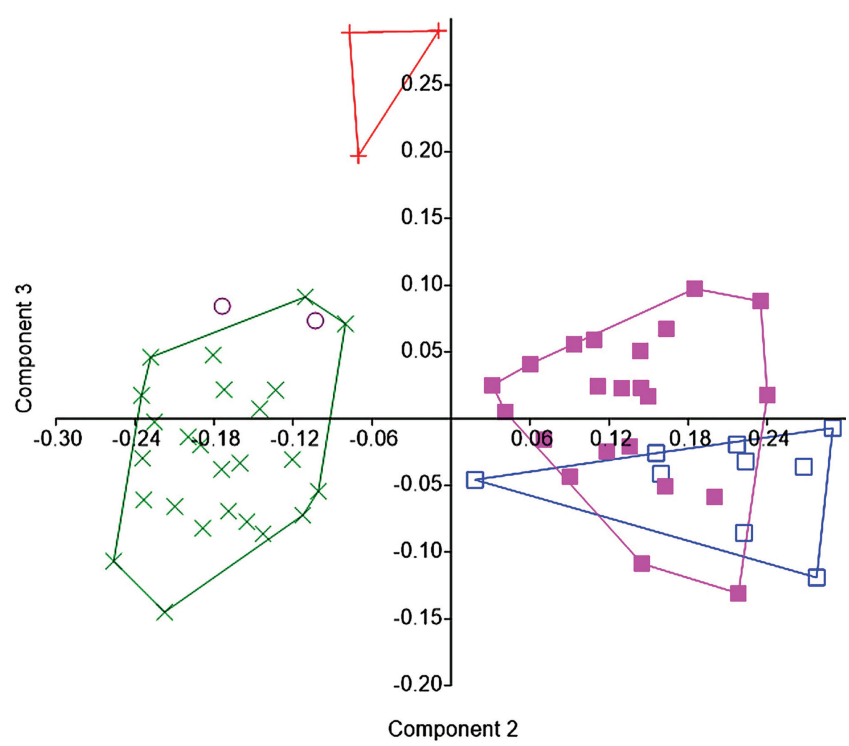

Fig. 13. Scatterplot of the second and third principal components calculated from combined samples of Rhyacoglanis annulatus (purple circle: $\mathrm{n}=2$ ), $R$. epiblepsis (green $\mathrm{x}: \mathrm{n}=25$ ), $R$. paranensis (pink squares; $\mathrm{n}=22), R$. pulcher $($ red $+; \mathrm{n}=3$ ) and $R$. seminiger (open blue squares; $\mathrm{n}=9$ ). 
Tab. 6. Variables loadings on the three first axes of the principal components analysis of combined samples of $R$. anulatus $(\mathrm{N}=2)$, $R$. epiblepsis $(\mathrm{N}=25)$, Rhyacoglanis paranensis $(\mathrm{N}=22), R$. pulcher $(\mathrm{N}=3)$ and $R$. seminiger $(\mathrm{N}=9)$. Variables with greater loadings $=*$.

\begin{tabular}{lccc}
\hline & Axis 1 & Axis 2 & Axis 3 \\
\hline Standard length & 0.17 & -0.03 & 0.05 \\
Head length & 0.20 & -0.01 & -0.03 \\
Pectoral-girdle width & 0.21 & -0.01 & -0.04 \\
Predorsal length & 0.18 & -0.04 & -0.03 \\
Dorsal-fin base length & 0.19 & 0.03 & -0.08 \\
Adipose-fin base length & 0.18 & $-0.19^{*}$ & 0.08 \\
Prepelvic length & 0.19 & 0.02 & 0.04 \\
Distance between pelvic and anal fins & 0.17 & -0.17 & 0.06 \\
Anal-fin base length & 0.16 & -0.08 & -0.04 \\
Caudal-peduncle length & 0.17 & 0.03 & $0.21^{*}$ \\
Body depth & 0.23 & 0.14 & $-0.27^{*}$ \\
Caudal-peduncle depth & 0.21 & -0.14 & -0.06 \\
Pectoral-fin spine length & 0.13 & $0.23^{*}$ & $0.21^{*}$ \\
Dorsal-fin spine length & 0.10 & $0.33^{*}$ & $0.32^{*}$ \\
Pelvic-fin length & 0.17 & 0.15 & 0.12 \\
Postcleithral-process length & 0.17 & $0.31^{*}$ & -0.004 \\
Distance between dorsal and pelvic fins & 0.23 & 0.04 & -0.07 \\
Distance between pelvic fins & 0.19 & 0.006 & -0.03 \\
Distance between pelvic-fin and anus & 0.19 & 0.16 & -0.06 \\
Distance between anus and anal fin & 0.16 & $-0.58^{*}$ & $0.48^{*}$ \\
Eye diameter & 0.14 & -0.03 & $-0.36^{*}$ \\
Interorbital distance & 0.20 & 0.14 & 0.09 \\
Snout length & 0.21 & -0.02 & -0.02 \\
Mouth width & 0.22 & -0.07 & -0.06 \\
Head depth & 0.20 & $0.25^{*}$ & -0.16 \\
Maxillary-barbel length & 0.16 & 0.06 & 0.11 \\
Distance between anterior and posterior nostrils & 0.14 & -0.05 & 0.19 \\
Distance between posterior nostril and eye & 0.23 & $-0.36^{*}$ & $-0.42^{*}$ \\
Distance between posterior nostrils & 0.19 & 0.11 & $0.25^{*}$ \\
\hline \% variance of eigenvalues & 84.16 & 6.98 & 1.65 \\
\hline & & & \\
& & & \\
& & &
\end{tabular}

Unculiferous tubercles in species of Rhyacoglanis. Unculi are unicellular keratinous projections, specialized skin structures found across the main groups of Ostariophysi (Roberts, 1982) and observed in all pseudopimelodids. All species of Rhyacoglanis have small epidermal unculiferous tubercles. These unculiferous tubercles have a mammiliform shape, are rounded to elliptical, covered by unculi of irregular penta- to heptagonal-shapes, have a prominent irregular shaped apex (Fig. 14a). The length of their longest axis ranges from 60 to $120 \mu \mathrm{m}$ (mean $=82.3 \pm 18.5 \mu \mathrm{m} ; \mathrm{N}=22$ ). The unculiferous tubercles are usually more developed on the dorsal and lateral surfaces of the head and body with a highest density on the head, particularly the barbels, lips and around the orbit. On the dorsal, pectoral, pelvic and anal fins the unculiferous tubercles are limited to the rays. No unculiferous tubercles were detected ventrally on the abdomen. Unculiferous tubercles were observed in smaller specimens (16.0 mm SL, MZUSP 22505) indicating their presence is not related to sexual maturity. Unculiferous tubercles in $R$. annulatus and $R$. seminiger are larger and more conspicuous than in $R$. paranensis, $R$. epiblepsis and $R$. pulcher. Each unculus in $R$. paranensis and $R$. seminiger has several rounded projections with the one in the middle slightly larger (Fig. 14b).

Unculiferous tubercles tend to be most developed in substrate-dwelling Cypriniformes and Siluriformes inhabiting swift water habitats (Roberts, 1982). Tubercles likely decrease skin surface turbulence and, thus, reduce drag on the fish in a way comparable to denticles in shark skin (Oeffner, Lauder, 2012) and contribute to adaptation of Rhyacoglanis to its rheophilic ecology.

\section{Phylogenetic analysis}

Character descriptions. Forty-one morphological features are the basis of a phylogenetic analysis with two primary goals: 1) to test the hypothesis of the monophyly of the new genus and its position in the Pseudopimelodidae and related groups; and 2) to determine the interrelationships of the included species. Characters are discussed by morphological systems. See (S1 - Available only as online supplementary file accessed with the online version of the article at http:// www.scielo.br/ni) for phylogenetic character matrix.

Skin and dermal structures. 1. Unculiferous tubercles: (0) absent; (1) present (CI 1,00; RI 1.00).

Unculiferous tubercles are present in all pseudopimelodids, butabsent in outgroup taxa(Heptapteridae and Pimelodidae; Birindelli, 2014). According to Roberts (1982), tubercles with unculi are common across the Siluriformes; however, Arratia, Huaquin (1995) noted their absence in Diplomystes. Birindelli (2014) observed well developed unculiferous tubercles in both males and females of different species of the Amphiliidae, Aspredinidae, Eresthistidae, Sisoridae, the mochokid Chiloglanis, various doradids (Centrodoras, Leptodoras, Lithodoras, Megalodoras, Orinocodoras, Oxydoras, Pterodoras, Rhinodoras and Rhynchodoras), and pseudopimelodids (Cephalosilurus fowleri and Lophiosilurus alexandri). That author also observed the absence or weak development of unculiferous tubercles in both males and females of different species of the Auchenipteridae, Ariidae, Claroteidae, Diplomystidae, Heptapteridae, Ictaluridae, Malapteruridae, Nematogenyidae, Pangasiidae, Pimelodidae, Siluridae, Mochokidae (except Chiloglanis), and Doradidae (except for previously mentioned taxa). Presence of these structures is possibly primitive among catfishes with their loss in the Pimelodidae and Heptapteridae derived. That said, the presence of several rounded expansions on the unculi has not been encountered in genera of the Pseudopimelodidae outside Rhyacoglanis and potentially represents a generic synapomorphy.

2. Degree of development of unculiferous epidermal structures: (0) little developed; (1) well developed (CI 0.33 ; RI 0.33). 

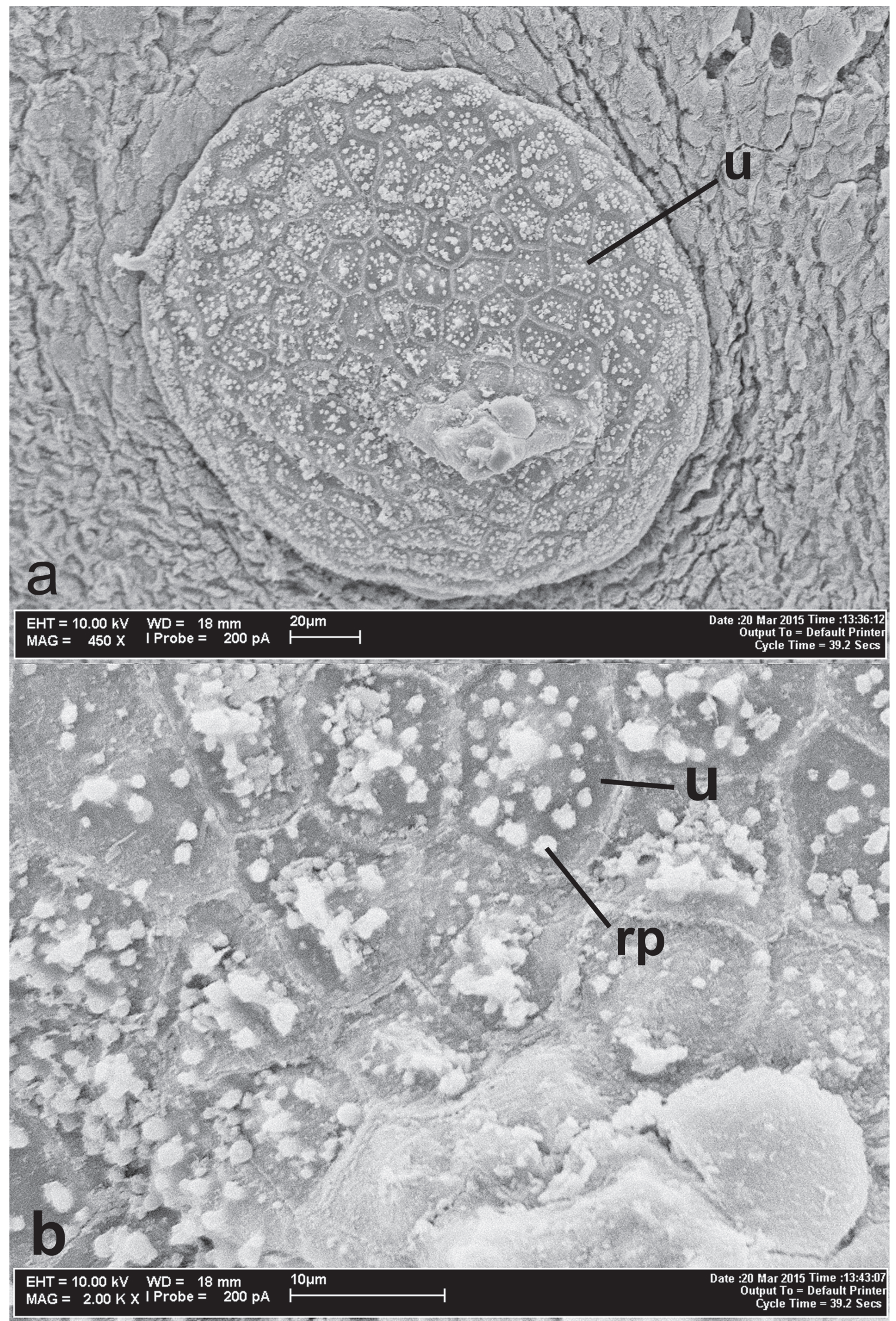

Fig. 14. a. Unculiferous tubercle of Rhyacoglanis seminiger $(\mathrm{u}=$ unculus $)$; b. detail of the same tubercle near the apex showing unculus with several rounded projections (rp). 
As mentioned above, unculiferous tubercles are absent or at best weakly developed in the outgroups (Heptapteridae, Pimelodidae, and Ictalurus punctatus). In Pseudopimelodus, Cruciglanis, Microglanis and Batrochoglanis these structures are very small and sparse, whereas they are very well developed in Cephalosilurus and Lophiosilurus. Rhyacoglanis demonstrates intrageneric variation in tubercle development with the structures poorly developed in $R$. paranensis, $R$. epiblepsis and $R$. pulcher vs. well developed in $R$. annulatus and $R$. seminiger.

3. Skin covering pectoral-fin spine: (0) thin; (1) thick (CI 1.00; RI 1.00).

Thin skin covers the pectoral-fin spine in the outgroup and pseudopimelodids except for Pseudopimelodus and Rhyacoglanis. Those two genera have thick skin covering the spine to a degree that it masks the anterior serrations. For this classification, visual inspection was carried out, wherein the thin skin has been identified as the anterior serrae and pectoral spine could be seen in preserved specimens.

4. Axillary pore: (0) present; (1) absent (CI 0.50; RI $0.50)$.

An axillary pore associated with mucous-producing glandular tissue (Birindelli, 2014) occurs ventral to the anteriormost region of the posterior cleithral process in various siluriforms including the outgroups herein. In the Pseudopimelodidae, the pore is absent exclusively in Batrochoglanis and Microglanis.

Pigmentation. 5. Light blotch on cheek: (0) absent; (1) present (CI 1.00; RI 1.00).

The head coloration pattern is quite variable in pseudopimelodids, ranging from very light in Cephalosilurus and Lophiosilurus (the same as in the outgroup), through grey in Cruciglanis and Pseudopimelodus, to completely black in Batrochoglanis and Microglanis. The head in Rhyacoglanis is slightly darker than the ground body coloration, with a subtle reduction in the pigmentation over the adductor mandibulae muscle. This character is inapplicable in the outgroup.

6. Dark band on predorsal region: (0) absent; (1) present (CI 0.50; RI 0.75).

Cephalosilurus, Lophiosilurus and the outgroup lack dark bands predorsally, including on the head. In Rhyacoglanis the head is slightly darker but the predorsal region remains light. A predorsal dark stripe is present in Pseudopimelodus, Cruciglanis, Batrochoglanis and Microglanis.

7. Fusion of dark predorsal and subdorsal bands: (0) absent (1) partial, (2) complete (CI 1.00; RI 1.00).

In Batrochoglanis and Microglanis the predorsal and subdorsal dark bands are completely fused, forming a large blotch on the anterior region of the body. Cruciglanis has the bands partially fused ventrally forming a V-shaped dark band. In Pseudopimelodus, the predorsal dark stripe is separated from the subdorsal dark band by a lightly colored area. The character is inapplicable in genera lacking a predorsal band.
8. Dark bands on body: (0) absent throughout ontogeny; (1) present at some point during ontogeny (CI 1.00; RI 1.00).

Dark body bands are widespread in the Pseudopimelodidae vs. the outgroup. Cephalosilurus and Lophiosilurus have dark bands as juveniles, but lose them during further development.

9. Fusion of dark subdorsal and subadipose bands: (0) absent; (1) present (CI 0.50; RI 0.00)

Separate dark subdorsal and subadipose bands are generally present in Pseudopimelodidae except for Batrochoglanis raninus and Rhyacoglanis seminiger in which these bands fuse along their proximate margins. This character is inapplicable in the outgroup which lacks such bands.

10. Small scattered spots on lateral surface of body: (0) limited in number and black; (1) numerous but grey (autapomorphy).

A limited number of black spots scattered laterally on the body is the common condition in the Pseudopimelodidae and outgroup. Large numbers of grey spots characterize Rhyacoglanis epiblepsis. Steindachneridion scriptum has scattered black dots and short lines but no small spots on the body.

11. Dark caudal-fin stripe: (0) absent; (1) present (CI 0.50; RI 0.75).

A dark caudal-fin stripe is absent in the outgroup plus Cephalosilurus and Lophiosilurus. Such a stripe is present in Cruciglanis, Pseudopimelodus, Batrochoglanis, Microglanis and Rhyacoglanis.

12. Convergence of middle of dark caudal-fin stripe with dark caudal-peduncle pigmentation: (0) absent; (1) present; (2) fin completely dark (CI 1.00; RI 1.00).

Although dark caudal-fin stripes occur in various pseudopimelodids, a confluence of that pigmentation and the dark band in the middle of the caudal peduncle is only present in Rhyacoglanis. In Cruciglanis, the caudal fin is completely dark, except on its distal margin that is light. This character is inapplicable in the outgroups which lack caudal-fin stripes.

Jaws. 13. Bifurcated dorsolateral process on premaxilla: (0) absent; (1) present (autapomorphy).

A premaxilla with a bifurcated dorsolateral process is restricted to the Pimelodidae (Lundberg et al., 1991b) as confirmed herein. In the Pseudopimelodidae the process is small, elongate but not bifurcate or is inconspicuous.

14. Premaxillary tooth plate form: (0) somewhat rounded; not posterolaterally extended; (1) posterolaterally extended (autapomorphy).

According to Birindelli (2014), a posterolateral extension of the premaxilla is limited to the Pimelodidae, Heptapteridae, Pseudopimelodidae and a subset of the Auchenipteridae (Auchenipterus, Epapterus). Within the Pseudopimelodidae, this extension is absent in Microglanis. 
Head and neurocranium. 15. Location of anterior nostril: (0) distant from margin of mouth; (1) near margin of mouth (CI 1.00; RI 1.00).

Pseudopimelodus, Cruciglanis and Rhyacoglanis and all species of the outgroup have the anterior nostril distant from anterior margin of the mouth. In Batrochoglanis, Microglanis, Cephalosilurus, and Lophiosilurus the anterior nostril is located along the mouth margin.

16. Vomer: (0) present; (1) absent (CI 1.00; RI 1.00).

The vomer is present across the outgroup as a plesiomorphy. Within the Pseudopimelodidae, it is present only in Pseudopimelodus, Cruciglanis and Rhyacoglanis.

17. Lateral ethmoid-autopalatine joint: (0) very short; (1) elongate (CI 1.00 RI 1.00 autapomorphy).

The lateral ethmoid-autopalatine joint in the Pimelodidae is elongate; a condition considered synapomorphic for the family (Lundberg et al., 1991b). In Ictalurus punctatus; the Heptapteridae and the Pseudopimelodidae the joint is very short.

18. Autopalatine: (0) depth similar anteriorly and posteriorly; (1) depth greater posteriorly; spoon-shaped (CI 1.00; RI 1.00).

Diogo et al. (2004) considered a spoon-shaped autopalatine with a rounded dorsoventrally expanded posterior region synapomorphic for the Pseudopimelodidae. In the outgroup, the autopalatine is of similar depth anteriorly and posteriorly; sometimes with the mid-dorsal and mid-ventral regions concave. These observations have been corroborated here.

Hyoid and gill arches. 19. Dorsal hypohyal: (0) present; (1) absent (CI 1.00; RI 1.00).

A dorsal hypohyal is present across the outgroups, and absent in the ingroup. Lundberg et al. (1991a) considered the absence of dorsal hypohyal a synapomorphy of Pseudopimelodidae. Mo (1991) and Birindelli (2014) noted that dorsal hypohyal is homoplastically absent in the Amphiliidae, Akysidae, Aspredinidae, Astroblepidae, Loricariidae, Sisoridae, Trichomycteridae, and the mochokid Chiloglanis.

20. Second basibranchial: (0) without lateral processes; (1) with lateral processes resulting in a cruciform shape (autapomorphy).

In most species of Pseudopimelodidae, the second basibranchial lacks lateral extensions as in the outgroup, whereas it is cruciform in Cruciglanis (Ortega-Lara, Lehmann, 2006).

21. Metapterygoid form: (0) longer than wide; (1) as long as wide (CI 1.00; RI 1.00).

Lundberg et al. (1991a) noted that species of the Pseudopimelodidae have a very short, quadrangular metapterygoid that is as long as wide, dorsally medially curved, and typically supported by a crest or rim. In the outgroup this bone is longer than wide.

22. Fenestra in quadrate: (0) absent; (1) present (CI 1.00; RI 1.00).
A rounded fenestra in the lower portion of the quadrate that articulates with the posterior of the anguloarticular is generally present across the Pseudopimelodidae. This fenestra was termed a cavity by Silfvergrip (1996) in Rhamdia quelen. The terms foramen (p. 26) or fenestra (p. 226) were applied by Mo (1991) to this structure in Bagrus bayad. Members of the Pimelodidae and Ictalurus punctatus lack the fenestra.

23. Distribution of gill rakers on first branchial arch: (0) along anterior margin of ceratobranchial; (1) restricted to posterior region of anterior margin of ceratobranchial (CI 1.00; RI 1.00).

According to Rocha (2012:102), gill rakers in the Siluriforms are usually distributed along the entire anterior margins of the first ceratobranchial. They are restricted to the posterior region of this bone in the Pseudopimelodidae.

Appendicular and axial skeleton. 24. Shape of mesocoracoid arch (0) elongate; (1) triangular (CI 1.00; RI $1.00)$.

In most Siluriformes, the mesocoracoid forms a small arch along the posterior face of the pectoral girdle (Birindelli, 2014). In Pseudopimelodus, the mesocoracoid arch is triangular and in other examined species it is thin and elongate.

25. Posterior cleithral process: (0) elongate, more than half continuing posterior to margin of opercular membrane; (1) short, broadly covered by opercular membrane (CI 0.50 ; RI 0.67).

The posterior cleithral process is small in most catfishes (Birindelli, 2014). In Pseudopimelodus, Cephalosilurus and Lophiosilurus this process is very short. In other genera of the Pseudopimelodidae and the outgroup, the process is elongate, sometimes approaching or reaching the vertical through the dorsal-fin origin in Rhyacoglanis and Microglanis. This character is inapplicable in taxa lacking the posterior cleithral process.

26. Number of branched pectoral-fin rays: (0) 8 or more; (1) 7 ; (2) 6 ; (3) 5 (CI 0.75; RI 0.80)

Lundberg (1970) observed that most catfishes have six to eight branched pectoral-fin rays. Outgroups in our analysis have 8 or more rays (Ictalurus punctatus 9 , Steindachneridion scriptum 10, Rhamdia quelen 8-9). In the Pseudopimelodidae the number of rays varies from 5 to 7 , with Pseudopimelodus having 7, Batrochoglanis 6, Microglanis 5, Cephalosilurus 6, Lophiosilurus 7, Cruciglanis 7, and Rhyacoglanis 6.

27. Height of serrae along anterior and posterior margins of pectoral-fin spine: (0) shorter anteriorly; (1) all of same approximate length (CI 0.50; RI 0.80).

In outgroup species, the serrae of the anterior margin of the pectoral fin spine are shorter than those along the posterior margin. This condition also occurs in Pseudopimelodus, Cruciglanis, Rhyacoglanis paranensis, $R$. seminiger and $R$. pulcher. Other genera of the Pseudopimelodidae, $R$. annulatus and $R$. epiblepsis have anterior and posterior serrae of the same size. 
28. Distribution of serrae along anterior margin of pectoral-fin spine: (0) across entire margin; (1) restricted to base (CI 1.00; RI 1.00).

Anterior pectoral-spine serrae are typically distributed along the entire spine margin. Serrae are restricted to the base of the spine in Rhyacoglanis seminiger and R. pulcher.

29. Tip of pectoral-fin spine: (0) pointed; (1) bifurcated (CI 1.00; RI 1.00).

In Pseudopimelodus and Rhyacoglanis (Fig. 4), the tip of pectoral-fin spine is bifurcate. In outgroups and other genera of the Pseudopimelodidae, the tip is pointed. According to Vanscoy et al. (2015), the tip of pectoral spine grows via the distal fusion of individual fin-spine segments.

30. Joint between fifth and sixth centra: (0) not interdigitating; (1) deeply interdigitating (autapomorphy).

Pimelodidae have an interdigitated suture joining the fifth and sixth centra (Lundberg et al., 1991b). In other catfish families including the Pseudopimelodidae this joint does not interdigitate and the sixth centrum is free from the fifth.

31. Number of vertebrae: (0) 46 or more; (1) $36-45$; (2) 30-35 (CI 0.67; RI 0.83).

Numbers of vertebra typically vary from 38 to 45 in siluriforms (Birindelli, 2014). However, Batrochoglanis, Microglanis and Rhyacoglanis have no more than 35 vertebrae. In Pseudopimelodus, Cruciglanis, Cephalosilurus, Lophiosilurus and Rhamdia quelen, vertebral numbers range between 36 and 44. Outgroup species, Ictalurus punctatus and Steindachneridion scriptum have more than 45 vertebrae.

32. Dorsal-fin spine: (0) smooth anteriorly; (1) serrate anteriorly (CI 0.50 ; RI 0.83 ).

The anterior dorsal-fin spine margin is smooth in the outgroups; a condition also observed in Diplomystes. As noted by Rocha (2012) and confirmed here, the anterior dorsal-fin margin bears antrorse serrae in Pseudopimelodus and Rhyacoglanis.

33. Caudal-fin shape: (0) forked with pointed lobes; (1) forked with rounded lobes; (2) emarginated; (3) rounded (CI $=0.60 ;$ RI 0.50).

Two forked caudal-fin lobe shapes occur in Rhyacoglanis - pointed vs. rounded. In Pseudopimelodus the caudal fin is forked with pointed lobes. In juveniles of Batrochoglanis villosus the caudal fin is emarginate and in adults of the species it is rounded. The caudal fin is rounded in Cephalosilurus fowleri and Lophiosilurus alexandri.

34. Length of ventral vs. dorsal caudal-fin lobes: (0) lobes approximately equal; (1) ventral lobe longer; (2) dorsal lobe longer (CI 0.50; RI 0.67).

In Cruciglanis pacifici, Rhamdia quelen and the species of Rhyacoglanis, the ventral lobe of the caudal fin is longer than the dorsal. Other genera of the Pseudopimelodidae and outgroup have lobes of similar lengths, or in Microglanis the dorsal is the longer.

Gas bladder. 35. Gas bladder: (0) heart-shaped; (1) dumbbell-shaped (CI 1.00; RI 1.00).
A large, heart-shaped gas bladder occurs in the outgroup in Cephalosilurus, Lophiosilurus, Microglanis, and Batrochoglanis. In Pseudopimelodus, Cruciglanis and Rhyacoglanis the small gas bladder has two lateral subcircular sacs united medially by a flattened region yielding an overall dumbbell form (Birindelli, Shibatta, 2011).

36. Constrictor muscle of gas bladder: (0) absent; (1) present (CI 0.50; RI 0.50)

The constrictor muscle is present only in the Pimelodidae, Lophiosilurus and Cephalosilurus in siluriforms (Birindelli, Shibatta, 2011, character 1). Repetitive muscle contraction is responsible for sound production by the gas bladder (Fine, Ladich, 2003). This mechanism differs from the elastic spring in doradids and auchenipterids, in which sound production is via repeated contraction of protractor muellerianus muscle (Fine, Ladish, 2003).

37. Lateral trabeculae on internal T-shaped gas bladder septum: (0) absent; (1) present (CI 0.50; RI 0.67).

According to Birindelli, Shibatta (2011, character 2), Ictalurus punctatus, Steindachneridion scriptum, Cephalosilurus and Lophiosilurus have lateral trabeculae on the internal T-shaped gas bladder septum. Lateral trabeculae are absent in Rhamdia, Pseudopimelodus, Cruciglanis, Rhyacoglanis, Batrochoglanis and Microglanis.

38. Size of pseudotympanum opening: (0) large; (1) small (CI 0.50; RI 0.83).

The pseudotympanum opening is a reduction of the hypaxialis muscle in the body wall lateral to the anterior portion of the swimbladder (Dutra et al., 2015). In Pseudopimelodus, Cruciglanis, and Rhyacoglanis is small, vs. large in outgroups, and in Batrochoglanis, Microglanis, Lophiosilurus and Cephalosilurus. According Birindelli, Shibatta (2011, character 5) this feature varies according to relative swimbladder size.

Laterosensory system. 39. Lateral line: (0) complete; (1) incomplete but long; extending beyond vertical through adipose fin; (2) incomplete and short; falling short of vertical through adipose fin (CI 0.50; RI 0.00).

The lateral line is complete in all outgroup taxa, in Pseudopimelodus, Cephalosilurus, and Lophiosilurus. In Rhyacoglanis epiblepsis and Batrochoglanis raninus, the lateral line is incomplete but extends beyond the vertical through the posterior limit of the adipose fin. In Microglanis, the lateral line is even shorter and does not extend beyond the vertical through the anterior limit of the adipose fin.

40. Cephalic lateral line: (0) unbranched; (1) branched (autapomorphy).

The dendritic arrangement of the laterosensory canals of the head and anterior portion of the body is an unambiguous synapomorphy of the Pimelodidae (Lundberg et al., 1991b). No pseudopimelodids shows this pattern.

Morphometric character. 41. Maxillary barbel length: (0) long; extending beyond vertical through dorsal-fin origin; (1) short; falling short of vertical through dorsal-fin origin (CI 1.00; RI 1.00). 
This character is quite variable across catfishes. Within the context of this phylogeny, it is noteworthy that all pseudopimelodids have short maxillary barbels $v s$. long barbels in the outgroup.

Phylogeny. A single tree resulted from the phylogenetic analysis, with consistency index of 0.71 and retention index of 0.82 ; demonstrating that few characters are homoplastic (Fig. 15; S2 - Available only as online supplementary file accessed with the online version of the article at http:// www.scielo.br/ni). In this phylogenetic analysis, the sister group of the Pseudopimelodidae was the Heptapteridae on the basis of three synapomorphies $(22(0>1), 31(0>1)$, $37(1>0))$.

Monophyly of the Pseudopimelodidae is robustly supported by eight synapomorphies $(1 \quad(0>1), 8(0>$ 1), $18(0>1), 19(0>1), 21(0>1), 23(0>1), 26(0>$ $2)$, and $41(0>1))$. Within the family, the clade formed by Lophiosilurus and Cephalosilurus shares four synapomorphies $(2(0>1), 25(0>1), 36(0>1)$ and $37(0>$ $1)$ ), and that clade, in turn, shares three synapomorphies $(15(0>1), 16(0>1)$, and $27(0>1))$, with its sister formed by Batrochoglanis and Microglanis, a clade supported by four synapomorphies $(4(0>1), 6(0>1) 7(0>2)$, and 31 (1>2)). The clade ((Cruciglanis, Pseudopimelodus) Rhyacoglanis) is supported by four synapomorphies $(3(0>1), 29(0>1), 35(0>1), 38(0>1))$. The sister relationship between Cruciglanis and Pseudopimelodus is supported by two synapomorphies (6 ( $0>1)$, and 26 $(2>1))$. Pseudopimelodus has two synapomorphies (24 $(0>1)$, and $25(0>1))$.
The monophyly of Rhyacoglanis is supported by three synapomorphies (characters $5(0>1), 12(0>1)$, and 31 (1> $2)$ ). The synapomorphies are: presence of a lightly colored area on the cheek, presence of a dark caudal-fin dark stripes confluent with the dark band on the middle of the caudal peduncle, and a reduction in the number of vertebrae, to a count of between $30-35$. The phylogenetic hypothesis is only partially resolved intragenerically and indicates that Rhyacoglanis paranensis forms a polytomy with the clades $R$. epiblepsis plus $R$. annulatus (supported by character $27(0>1)$, and $R$. pulcher plus $R$. seminiger (supported by character $28(0>1))$.

\section{Discussion}

Taxonomy and diversity. Taxonomic problems centered on Rhyacoglanis are longstanding as documented in the synonymy of $R$. pulcher. Various new combinations for the species were proposed as authors grappled with issues of generic limits. Lundberg et al. (1991a) made progress in addressing this problem; however, the discovery of new genera by Ortega-Lara, Lehmann (2006) and herein along with the series of new species of Rhyacoglanis described in this paper demonstrates that this family still contains many taxa not yet discovered. The intraspecific variation in some Rhyacoglanis species, the limited available material of the genus, the major gaps in the known distribution of the genus, and the problems in collecting in the high energy settings preferred by these rheophilic species make it very likely that species of the genus remain undiscovered; a situation common for the Neotropical ichthyofauna (Vari, Malabarba, 1998).

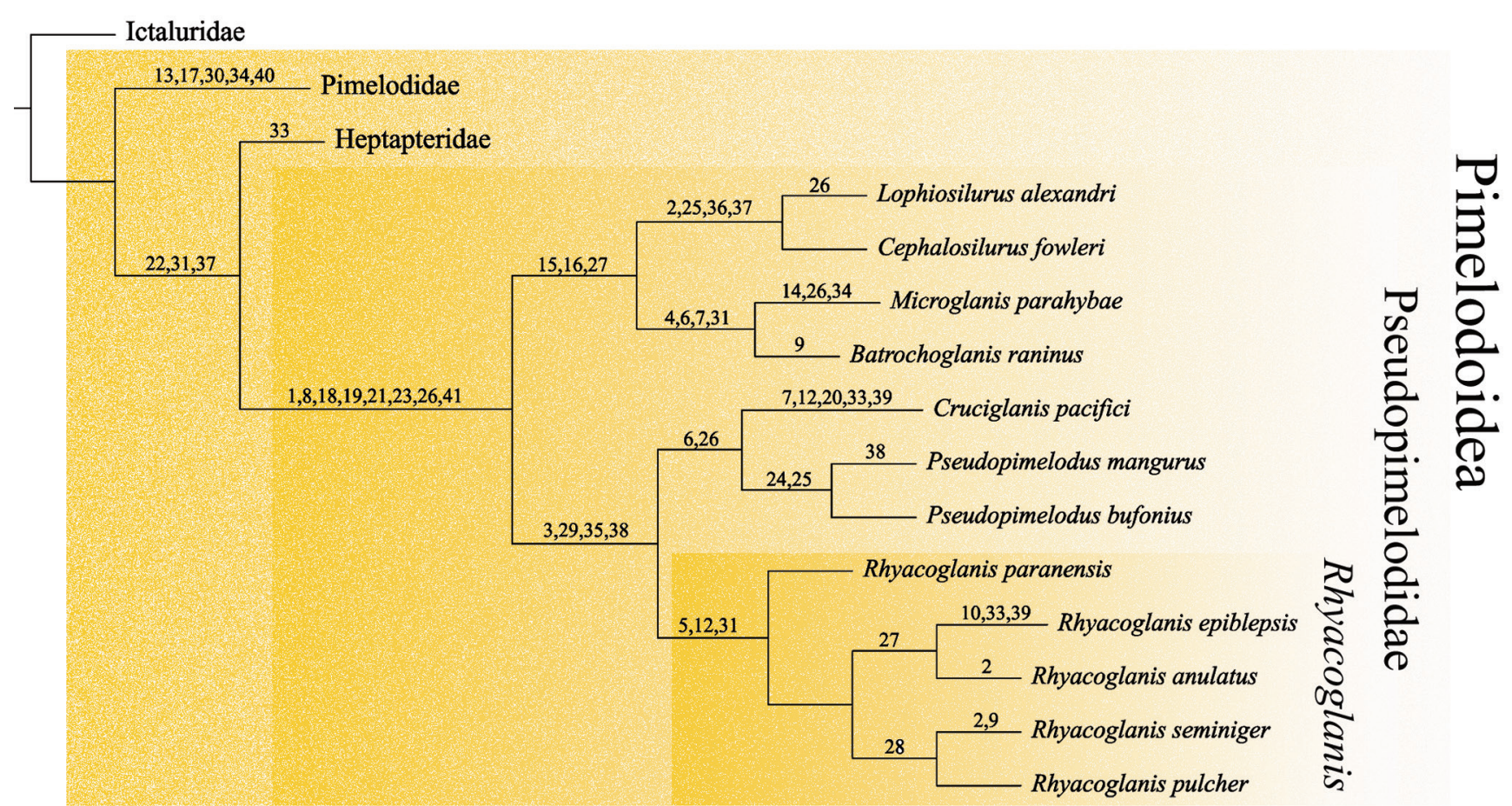

Fig. 15. Tree of phylogenetic relationship in Pseudopimelodidae $(C I=0.71 ; R I=0.82$; tree length $=70)$. Numbers correspond to those of character descriptions, and Appendices 1 and 2. 
Phylogenetic reconstruction. Phylogenetic relationships between the Heptapteridae, Pimelodidae and Pseudopimelodidae are a problem that warrants continued attention. Monophyly of each of the families has been corroborated by morphological (Diogo et al., 2004; Diogo, 2007) and molecular data (Hardman, 2005; Sullivan et al., 2006; Sullivan et al., 2013), and evidence supporting monophyly of the superfamily composed of those three families, called Pimelodoidea, was presented by Sullivan et al. (2006).

A sister relationship between the Heptapteridae and Pseudopimelodidae proposed herein was advanced by Lundberg et al. (1991a) and Britto (2002). Our analysis supports this hypothesis with three characters, which are hypothesized as synapomorphies of the two families. The first is an anteroventral fenestra in the quadrate that accommodates the end of the posterodorsal process of the anguloarticular and facilitates lower jaw movement and mouth opening. A similar fenestra arose homoplastically in the Bagridae (Mo, 1991). The second character involving the low vertebral counts, is somewhat tentative, and may be refined when data from an increased number of species of the Heptapteridae and Pimelodidae are available. Low numbers of vertebrae demonstrate size-related homoplasy in the Pseudopimelodidae as observed in Microglanis and Rhyacoglanis, both of which have the lowest counts and smallest body size, but are not sister groups. Absence of lateral trabeculae in the gas bladder is the third character uniting the Heptapteridae and Pseudopimelodidae. It is of note that the absence of such structures may be plesiomorphic in the Siluroidei in so far as they are also absent in Diplomystidae (Marceniuk, Birindelli, 2010). In sum, much of the evidence supporting a sister relationship of the Pseudopimelodidae and Heptapteridae is equivocal and this question requires further study. Indeed, swim bladder morphology (Birindelli, Shibatta, 2011) and molecular (Sullivan et al., 2013) evidence indicates a sister relationship of the Pseudopimelodidae with the Pimelodidae rather than the Heptapteridae.

Monophyly of the Pseudopimelodidae as supported in this study was corroborated in prior publications by Lundberg et al. (1991a), Sullivan et al. (2006) and Sullivan et al. (2013). Four of the eight characters that support this relationship were highlighted by previous authors: absence of a dorsal hypohyal (Lundberg et al., 1991a), the foreshortened metapterygoid (Lundberg et al., 1991a), the spoon-shaped autopalatine (Diogo, 2004), and the distribution of gill-rakers along the first ceratobranchial (Rocha, 2012). Among the newly discovered characters, the presence of unculiferous tubercles was noted by Birindelli (2014), but its significance in the evolution of the Pseudopimelodidae was not discussed. Within the context of the Pimelodoidea, the form of the unculiferous tubercles resolves as a synapomorphy of the Pseudopimelodidae since this type of structure is absent in the Heptapteridae and Pimelodidae. The same reasoning applies to the dark body bands, low number of pectoral-fin branched rays and short maxillary barbels in the Pseudopimelodidae vs. the absence of that pigmentation, high number of branched rays and longer barbels in the Heptapteridae and Pimelodidae.

This study provides the best resolved intergeneric phylogenetic reconstruction for Pseudopimelodidae to date, with no polytomies and all branches supported by two or more synapomorphies. The hypothesized relationships are, in part, incongruent with those proposed by earlier authors. Our results demonstrate that the group consisting of Cruciglanis, Pseudopimelodus and Rhyacoglanis is the sister of the remainder of the Pseudopimelodidae with Cephalosilurus and Lophiosilurus forming the sister group of Batrochoglanis and Microglanis. Lundberg et al. (1991a) alternatively considered Pseudopimelodus (Zungaro therein) as the sister of all other genera of the Pseudopimelodidae (their study did not include the thenundescribed Cruciglanis and Rhyacoglanis). Genera of the Pseudopimelodidae were represented in that study by only one or two species and all but Cephalosilurus showed autapomorphies. Many of these autapomorphies resolve as synapomorphies with the inclusion of additional species (Shibatta, 1998). The consensus tree presented by Shibatta (1998) included a polytomy between Batrochoglanis, Microglanis and Cephalosilurus. Shibatta (2003b) later presented one of the equally most parsimonious trees wherein Pseudopimelodus is sister of Microglanis + Batrochoglanis and Cephalosilurus + Lophiosilurus. Ortega-Lara, Lehmann (2006) added characters to Shibatta's (1998) matrix yielding a more resolved intrafamilial phylogeny, but in which Cephalosilurus and Lophiosilurus are sister to all other genera. Most recently, Birindelli, Shibatta (2011) presented two alternative phylogenetic hypotheses based on gas bladder features. These partly corroborate Ortega-Lara, Lehmann's (2006) hypothesis if the Pimelodidae is designated as outgroup. When, however, the outgroup is the Heptapteridae, the obtained relationships are most similar to Shibatta's (1998) hypothesis, including incomplete resolution of intergeneric relationships. The molecular analysis of Sullivan et al. (2013) yielded a scheme of relationships that differs greatly from prior morphology-based hypotheses, with Batrochoglanis sister to a clade formed by Cephalosilurus, Lophiosilurus and Pseudopimelodus.

We find Rhyacoglanis to be monophyletic and sister to Cruciglanis and Pseudopimelodus. This agrees in part with the Shibatta (1998) hypothesis in that Pseudopimelodus and Rhyacoglanis constitute a monophyletic group (Rhyacoglanis being represented in the Shibatta study by Pseudopimelodus pulcher). Birindelli, Shibatta (2011) found no differences in the gas bladder morphology of Pseudopimelodus pulcher (=Rhyacoglanis pulcher) vs. the examined species of Pseudopimelodus as that genus is treated herein, and Cruciglanis. In that study, as in this, the evidence supports the hypothesis of a sister relationships of Cruciglanis, Pseudopimelodus and Rhyacoglanis. 
Comparative material. Specimens listed in Shibatta, Pavanelli (2005), Shibatta (2014, 2016), and the following: Cruciglanis pacifici Ortega-Lara \& Lehmann, 2006: Colombia: INCIVA(IMCN) 113, 1, 91.6 mm SL. Cephalosilurus albomarginatus Eigenmann, 1912: Guyana: FMNH 53221, holotype, 75 mm SL. FMNH 53222, 8, 21.5-58.5 mm SL. ROM 61482, 2, 50.5-78.8 mm SL. FMNH 53572, paratype, $68.8 \mathrm{~mm}$ SL. ROM 61336, 27, 29.0-88.4 mm SL. Cephalosilurus apurensis Mees, 1978: Venezuela: USNM 260213, 1, $226.4 \mathrm{~mm}$ SL. MBUCV-V-15379, 1 of 2, $165.25 \mathrm{~mm}$ SL. Cephalosilurus fowleri Haseman, 1911: Brazil: FMNH 54254, holotype, $301.4 \mathrm{~mm}$ SL. MCP 16675, 2, 44.9-128,0 mm SL. ANSP 172158, 2, 39.2-199.5 mm SL. MCP 14094, 1, 328.8 mm SL. MCP 14126, 1, 262.7 mm SL. MZUSP 38097, 1, 244.6 mm SL. MZUSP 24647, 1, 277.0 mm SL. MZUEL 12095, 1 c\&s, 145.4 mm SL. Ictalurus punctatus Rafinesque, 1818: United States: USNM 244951, 25, 145,6-178,0 mm SL. Lophiosilurus alexandri Steindachner, 1876: Brazil: MZUEL 55542, 1 skeleton, 290 mm SL. Pseudopimelodus bufonius (Valenciennes, 1840): Brazil: INPA 1979, 1, 32.4 mm SL. INPA 4884, 1, 203,4 mm SL. INPA 9514, 4, 56.3-87.9 mm SL. INPA 6202, 1, 139,0 mm SL. INPA 8058, 1, 68.8 mm SL. INPA 9516, 7, 66.4-95.6 mm SL. Pseudopimelodus charus (Valenciennes, 1840): Brazil: MZUSP 39278, 1, 93.4 mm SL. MZUSP 39752, 3, 121.2123.4 mm SL. ANSP 172157, 2, 70.0-71.6 mm SL. ANSP 172156, 1, 53.4 mm SL. Pseudopimelodus mangurus (Valenciennes, 1835): Brazil: MZUEL 828, 1, 56.2 mm SL. MZUEL 830, 2, 54.4-59.4 mm SL. MZUEL 829, 1, 140.8 mm SL. MZUEL 1073, 1, 185.2 mm SL. MCP 10336, 1, 129.0 mm SL. MCP 12685, 1, $146.1 \mathrm{~mm}$ SL. MCP 13087, 1, 173.7 mm SL. Argentina: MCP 44779, 2, 123.5-134.7 mm SL. Pseudopimelodus schultzi (Dahl, 1955): Colombia: USNM 121258, 1, 150.2 mm SL. USNM 175310, 1, 99.9 mm SL. Rhamdia quelen Quoy \& Gaimard, 1824: Brazil: MZUEL 11664, 2 skeleton, not measured. Steindachneridion scriptum (Miranda Ribeiro, 1918): Brazil: MZUEL 6695, 1 skeleton, not measured.

\section{Acknowledgments}

We thank Susan Raredon, Jeff Clayton and Scott Whittaker for assistance at USNM. Mark Sabaj-Pérez, John Lundberg and Tiago Carvalho hosted OAS at ANSP. Scott A. Schaefer and Barbara Brown (AMNH), James MacLaine (BMNH), Lucia Py-Daniel and Renildo Ribeiro de Oliveira (INPA), Claudio Oliveira (LBP), Flavio Bockmann (LIRP), and Mário de Pinna, Aléssio Datovo and Osvaldo Oyakawa (MZUSP) generously made specimens available from their respective collections. José Luis O. Birindelli and Fernando C. Jerep provided input into the characters used in phylogenetic analysis and their analysis. Maurice Kottelat, Ralf Britz, Sven Kullander, Brian Sidlauskas, and two anonynous reviewers suggested substantial improvements to the mauscript. Rony Suzuki provided the photograph of a live specimen. This sabbatical study was carried out by OAS at the Smithsonian Institution under support from $\mathrm{CNPq}$ (Pós-doutorado no Exterior, proc. 200280/2014-7) and the Böhlke Endowment of ANSP. OAS is a research fellow of the Conselho Nacional de Desenvolvimento Científico e Tecnológico (CNPq Proc. 304868/2015-9).

\section{References}

Arratia G. Catfish head skeleton - an overview. In: Arratia G, Kapoor BG, Chardon M, Diogo R, editors. Catfishes. Enfield: Science Publishers, Inc.; 2003a. p.3-46.

Arratia G. The siluriform postcranial skeleton - an overview. In: Arratia G, Kapoor BG, Chardon M, Diogo R, editors. Catfishes. Enfield: Science Publishers, Inc.; 2003b. p.121-157.

Arratia G, Huaquin L. Morphology of the lateral line system and of the skin of diplomystid and certain primitive loricarioid catfishes and systematic and ecological considerations. Bonn Zool Monogr. 1995; (36):1-109.

Birindelli JLO. Phylogenetic relationships of the South American Doradoidea (Ostariophysi: Siluriformes). Neotrop Ichthyol. 2014; 12(3):451-564.

Birindelli JLO, Shibatta OA. Morphology of the gas bladder in bumblebee catfishes (Siluriformes, Pseudopimelodidae). J Morphol. 2011; 272(7):890-96.

Boulenger GA. An account of the fishes collected by Mr. C. Buckley in eastern Ecuador. Proc Zool Soc Lond. 1887; (14):274-83.

Britto MR. Análise filogenética da ordem Siluriformes com ênfase nas relações da superfamília Loricarioidea (Teleostei: Ostariophysi). [PhD Thesis]. São Paulo, SP: Universidade de São Paulo; 2002.

Castro RMC. Evolução da ictiofauna de riachos sul-americanos: padrões gerais e possíveis processos causais. In: Caramaschi EP, Mazzoni R, Peres-Neto PR, editors. Ecologia de peixes de riachos. Rio de Janeiro: PPGE-UFRJ; 1999. p.139-155. (Oecologia Brasiliensis; vol 6).

Diogo R. Osteology and myology of the cephalic region and pectoral girdle of Heptapterus mustelinus, comparison with other Heptapterins, and discussion on the synapomorphies and phylogenetic relationships of the Heptapterinae and the Pimelodidae (Teleostei: Siluriformes). Int J Morphol. 2007; 25(4):735-48.

Diogo R, Chardon M, Vandewalle P. Osteology and myology of the cephalic region and pectoral girdle of Batrochoglanis raninus, with a discussion on the synapomorphies and phylogenetic relationships of the Pseudopimelodinae and Pimelodidae (Teleostei: Siluriformes). Anim Biol. 2004; 54(3):261-80.

Dutra GM, Jerep FC, Vari RP, Santana CD. The pseudotympanum in the Gymnotiformes (Teleostei, Ostariophysi, Otophysi): homology and evolution of a previously unexplored system in Neotropical electric fishes. Zool J Linnean Soc. 2015; 174(1):114-29.

Eigenmann $\mathrm{CH}$. Catalogue of the fresh-water fishes of tropical and south temperate America. In: Scott, WB, editor. Reports of the Princeton University Expeditions to Patagonia 1896-1899. Princeton: Princeton University; 1910. vol 3, Zoology, pt 4; 375-511.

Eigenmann $\mathrm{CH}$. The freshwater fishes of British Guiana, including a study of the ecological grouping of species and the relation of the fauna of the plateau to that of the lowlands. Carnegie Institute; 1912.

Eigenmann CH, Eigenmann RS. Preliminary notes on South American Nematognathi. Proc Calif Acad Sci. 1888; 1:119-72. pt 1. 
Eigenmann CH, Eigenmann RS. A revision of the South American Nematognathi or Catfishes. Occas Pap Calif Acad Sci. 1890; (1): $1-508$.

Eschmeyer WN, Fong JD. Species by family/subfamily in the Catalog of fishes. [Electronic version]. San Francisco (CA): California Academy of Sciences; 2017. [cited 2017 Jan 03]. Available from: http://researcharchive.calacademy.org/research/ ichthyology/catalog/SpeciesByFamily.asp

Fine ML, Ladich F. Sound production, spine locking, and related adaptations. In: Arratia G, Kapoor BG, Chardon M, Diogo R, editors. Catfishes. Enfield: Science Publishers, Inc.; 2003. p.249-290.

Goloboff PA, Farris JS, Nixon KC. TNT, a free program for phylogenetic analysis. Cladistics. 2008; 24(5):774-86.

Gosline WA. Synopsis of the genera of pimelodid catfishes without a free orbital rim. Stanford Ichthyol Bull. 1941; 2(3):83-88.

Hammer O, Harper DAT, Ryan PD. PAST: Paleontological Statistics software package for education and data analysis. Palaeontol Electron. 2001; 4(1):1-9.

Hardman M. The phylogenetic relationships among non-diplomystid catfishes as inferred from mitochondrial cytochrome $b$ sequences; the search for the ictalurid sister taxon (Otophysi: Siluriformes). Mol Phylogenet Evol. 2005; 37(3):700-20.

International Union for Conservation of Nature (IUCN). Standards and Petitions Subcommittee. Guidelines for using the IUCN Red List Categories and Criteria. Version 12 [Internet]. 2016 [updated 2016 Feb]. Available from: http://cmsdocs.s3.amazonaws.com/ RedListGuidelines.pdf

Jolicoeur P, Mosimann JE. Size and shape variation in the painted turtle. A principal component analysis. Growth. 1960; 24(4):339-54.

Langeani F, Castro RMC, Oyakawa OT, Shibatta OA, Pavanelli CS, Casatti L. Diversidade da ictiofauna do Alto Rio Paraná: composição atual e perspectivas futuras. Biota Neotrop. 2007; 7(3):181-97.

Lundberg JG. The evolutionary history of North American catfishes, family Ictaluridae. [PhD Thesis]. Ann Arbor: University of Michigan; 1970.

Lundberg JG, Bornbusch AH, Mago-Leccia F. Gladioglanis conquistador $\mathrm{n}$. sp. from Ecuador with diagnoses of the subfamilies Rhamdiinae Bleeker and Pseudopimelodinae n. subf. (Siluriformes: Pimelodidae). Copeia 1991a.; (1):190-209.

Lundberg JG, Mago-Leccia F, Nass P. Exallodontus aguanai, a new genus and species of Pimelodidae (Teleostei: Siluriformes) from deep river channels of South America and delimitation of the subfamily Pimelodinae. Proc Biol Soc Wash. 1991b; 104(4):840-69.

Lundberg JG, McDade L. A redescription of the rare Venezuelan Brachyrhamdia imitator Myers (Siluriformes, Pimelodidae), with phylogenetic evidence for a large infrafamilial lineage. Not Nat Acad Nat Sci Philadelphia. 1986; 463:1-24.

Marceniuk AP, Birindelli JLO. Morphology of the gas bladder in sea catfishes (Siluriformes: Ariidae). Zootaxa. 2010; 2579:59-68.

Mees GF. The Auchenipteridae and Pimelodidae of Suriname (Pisces, Nematognathi). Zool Verhandel. 1974; 132:3-248.

Miranda-Ribeiro A. Pimelodidae, Trachycorystidae, Cetopsidae, Bunocephalidae, Auchenipteridae, Hypophthalmidae. Rio de Janeiro: Comissão de Linhas Telegraphicas Estrategicas de Matto-Grosso ao Amazonas; 1914. vol 15, anexo 5.

Mo T. Anatomy, relationships and systematics of the Bagridae (Teleostei: Siluroidei) and siluroid phylogeny. Koenigstein: Koeltz Scientific Books; 1991. (Theses Zoologicae; vol 17).

Neff NA, Marcus LF. A survey of multivariate methods for systematics. New York: privately published; 1980.
Oeffner J, Lauder GV. The hydrodynamic function of shark skin and two biomimetic applications. J Exp Biol. 2012; 215(5):785-95.

Ortega-Lara A, Lehmann-A P. Cruciglanis, a new genus of pseudopimelodid catfish (Ostariophysi, Siluriformes) with description of a new species from the Colombian Pacific coast. Neotrop Ichthyol. 2006; 4(2):147-56.

Roberts TR. Unculi (horny projections arising from single cells), an adaptative feature of the epidermis of ostariophysan fishes. Zool Scr. 1982; 11(1):55-76.

Rocha MS. Sistemática da família Pimelodidae Swainson, 1838 (Teleostei: Siluriformes). [PhD Thesis]. Manaus, AM: Instituto Nacional de Pesquisas da Amazônia; 2012.

Shibatta OA. Sistemática e evolução da família Pseudopimelodidae (Ostariophysi, Siluriformes), com a revisão taxonômica do gênero Pseudopimelodus. [PhD Thesis]. São Carlos, SP: Universidade Federal de São Carlos; 1998.

Shibatta OA. Family Pseudopimelodidae (Bumblebee catfishes, dwarf marbled catfishes. In: Reis RE, Kullander SO, Ferraris CJ, Jr., organizers. Check List of the Freshwater Fishes of South and Central America. Porto Alegre: Edipucrs; 2003a. p.401-405.

Shibatta OA. Phylogeny and classification of Pimelodidae. In: Arratia G, Kapoor BG, Chardon M, Diogo R, editors. Catfishes. Enfield: Sciences Publishers, Inc.; 2003b. p.385-400.

Shibatta OA. A new species of Microglanis (Siluriformes: Pseudopimelodidae) from the upper rio Tocantins basin, Goiás State, Central Brazil. Neotrop Ichthyol. 2014; 12(3):81-87.

Shibatta OA. A new species of bumblebee catfish of the genus Microglanis (Siluriformes: Pseudopimelodidae) from upper rio Paraguay basin, Brazil. Neotrop Ichthyol. 2016; 14(3):525-32.

Shibatta OA, Pavanelli CS. Description of a new Batrochoglanis species (Siluriformes, Pseudopimelodidae) from the Rio Paraguai basin, State of Mato Grosso, Brazil. Zootaxa. 2005; 1092(1):21-30.

Silfvergrip AMC. Zungaro, a senior synonym of Paulicea (Teleostei: Pimelodidae). Ichthy Explor Fresh. 1992; 3:305-10.

Silvfergrip AMC. A systematic revision of the Neotropical catfish genus Rhamdia (Teleostei, Pimelodidae). Stockholm: Swedish Museum of Natural History; 1996.

Sullivan JP, Lundberg JG, Hardman M. A phylogenetic analysis of the major groups of catfishes (Teleostei: Siluriformes) using rag1 and rag2 nuclear gene sequences. Mol Phylogenet Evol. 2006; 41(3):636-62.

Sullivan JP, Muriel-Cunha J, Lundberg JG. Phylogenetic relationship and molecular dating of the major groups of catfishes of the Neotropical superfamily Pimelodoidea (Teleostei, Siluriformes). Proc Acad Nat Sci Philadelphia. 2013; 162(1):89-110.

Vanscoy T, Lundberg JG, Luckenbill KR. Bony ornamentation of the catfish pectoral-fin spine: comparative and developmental anatomy, with an example of fin-spine diversity using the tribe Brachyplatystomini (Siluriformes, Pimelodidae). Proc Acad Nat Sci Philadelphia. 2015; 164(1):177-212.

Vari RP, Malabarba LR. Neotropical Ichthyology: an overview. In: Malabarba LR, Reis RE, Vari RP, Lucena ZMS, Lucena CAS, editors. Phylogeny and Classification of Neotropical Fishes. Porto Alegre: Edipucrs; 1988. p.1-11. 